\title{
The Current State of the Law in Canada on Crown Obligations to CONSUlt AND ACCOMMODATE ABORIGINAL INTERESTS IN RESOURCE DEVELOPMENT
}

\author{
Heather L. Treacy," Tara L. Campbell," and Jamie D. Dickson".
}

The Supreme Court of Canoda has clarified that the dit! to consult with Aboriginal groups and, where indicated. to accommodate thelr interests lics with the Crown alone. In the context of project developmen. the dury to consult and accommodate may be sutisficd by the Crown providing opportmities for meaningfil involvement in regulatory and emirommental assessment processes and addressing Aboriginal concerns. This includes engaging directly with the Aboriginal group, soliciring and lisiening carcfully to concerns. and attempting to minimize the impert on Aboriginal rights. In recent decisions, the courts hav' repeatedly focused on the howour of the Crown and, in designing remedies, have emphasized the ne'ed to balance Aboriginal interests with those of the broader society: Where the duty to consult has not been satisfied, the courts have more frequenty ordered ongoing consultation and have less frequently quashed permits and approvals. Prudent project proponents will contimue to engage potentially affected $A$ horiginal groups in a meaningful wav. attempt o idemify, Aboriginal concerns, discuss with Abonjginal groups potential strategies to minimize or avoid infringements of Aboriginal rights, and coimmunicale accurately these efforts to government decision-makers.
La Cour supreme du Camada a pricise quo lobligation de consulter les groupes anfochomes e't. si indique. daccommoder letrs inferis incombe

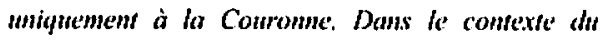
developpement de projet. I'obligation de consulter et d'accommoder peu èrre sarisfaile si la Couromme donne l'occasion de parficiper de manière imporfante aur processus d'évaluation enviromnememale et d'aborder les préoccupations des Aufochonex. Cela comprend s'engager auprès dit groupe aulochtome. ecouter soigneusement les préccupations ef essayer de minimiser l impact sur les droits des dubohones. Dams de récentes décisions, les Iribmanx onf, it maintes reprises, cible limporfance de lhouneur de la Couronme et, en cherchant des remedes, ont souligne' le besoin d'éguilibrer les intérèts anfochnomes ef ceux de la société en général. Si lobligation de consulter $n$ 'est pas satisfaite, les tribunaux ont demandi plus souvent des consultations cominues et ont cassé moins sonen des permis et des approbations. l.es iniriateurs prudents de projets combimeromt diuclure significarivement les groupes anfochomes porenticlloment touches. essaỵu de deverminer lewrs prisccupations et discufant de stratigies évenuselles ance les groupes ausochones afin do reduire on d'éviter la violation de droits autochtomes at communiquer efficacemen leurs efforts antr dicideurs du gouvernement.

\section{TABLE OF CONTENTS}

I. INTRODUCTION ........................ 572

II. A BRIEF OVERVIEW OF APPLICABLLE ABORIGINAL.

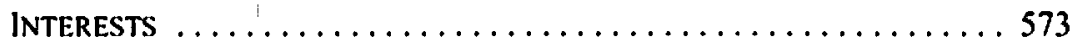

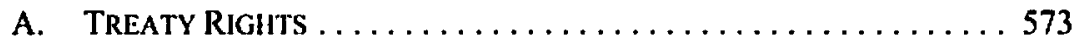

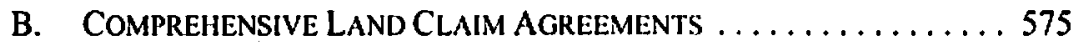

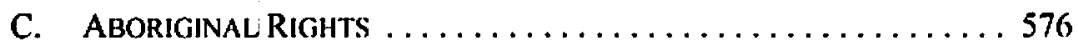

D. ABORIGINAL TITLE $\ldots \ldots \ldots \ldots \ldots \ldots \ldots \ldots \ldots \ldots \ldots \ldots \ldots \ldots$

E. MÉtIS RIGHTS ...................... 579

III. The Common Law Duty to Consult and Accommodate . . . . . . . 581

- Parner, Fraser Milner Casgrain LL.P. Calgary. Nlberta. The authors would like to stress that while this article was current to June 2006, the law in this area is constantly evolving. As such, readers are cncouraged to seck out the most recent pronouncements in the area.

-. Counsel, Fraser Milner Casgrain L.L.P. Vancouver, British Columbia

.. Associate, Fraser Milner Casgrain LLP. Calgary, Alberta. 
A. R. V. SPARROW ........................ 582

B. HAIDA NATION V. BRITISH COLUMBIA

(MINISTER OF FORESTS) ..................... 583

C. TAKU RIVER TLINGIT FIRST NATION V. BRITISH COLUMAIA

(PROJECT ASSESSMENT DIRECTOR) ................. 588

D. MIKISEW CREE FIRST NITION V. CANADA

(MINISTER OF Canadian HERITAGE) . ................ 590

E. Kliy Prounounctements on Crown Duties of

CONSULTATION AND ACCOMMODATION SET OUT IN HAIDA,

TAKU RIVER, AND MIKISEW . . . . . . . . . . . . . . . . 593

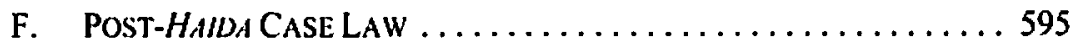

IV. Regulatory CONSUltation ReQuiRements and ProvinCial

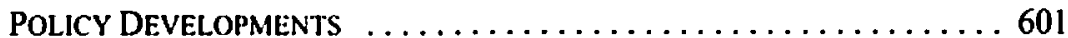

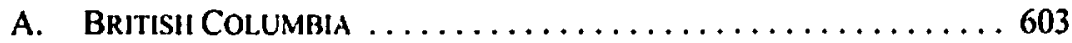

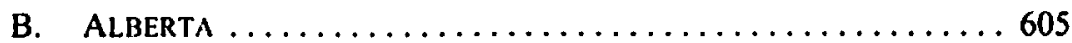

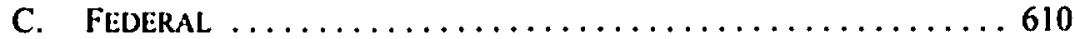

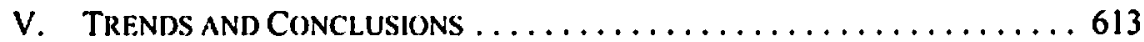

\section{INTRODUCTION}

Over the past two decades, there have been significant developments in the law regarding the nature, scope, and extent of Aboriginal interests in Canada. Over the past two years, there has been notable clarification of the law as it relates specifically to Crown obligations to consult with Aboriginal people and, where indicated, to accommodate Aboriginal interests prior to making project approval decisions that may impact these interests. Despite this welcome clarification, many key aspects of this dynamic area of the law remain unclear, including the nature of the specific role that resource developers are to play in these consultation and accommodation processes; the question of when the Crown's duty to accommodate, in addition to and as a result of consultation efforts, will be triggered; and the specific types of measures that will be required of the Crown in order to successfully discharge its accommodation obligations if they are triggered in any particular instance.

This article attempts to set out the current state of the law in this area. It examines the three recent and leading decisions rendered by the Supreme Court of Canada: Haida Nation v. British Columbia (Minister of Forests), ${ }^{1}$ Taku River Tlingil First Nation v. British Columbia (Project Assessment Director), ${ }^{2}$ and Mikisew Cree First Nation v. Canada (Minister of Canadian Heritage). ${ }^{3}$ It also looks at certain lower court decisions that have applied the general tests first set out in Haida and Taku River. It then describes certain regulatory requirements for consultation with Aboriginal people with respect to federally regulated energy projects and provincially regulated projects in both Alberta and British Columbia. The article also addresses the specific provincial policy documents in place in both Alberta and British Columbia that purport to mandate a framework for how Crown obligations of consultation and accommodation are to be administered in each respective 
province. Finally, it draws some general conclusions, and comments on the practical realities of the consultation and accommodation processes with Aboriginal people, including the specific role of the project proponent.

\section{A BRIEF OVERVIEW OF APPLICABI. ABORIGINAL INTERESTS}

There are many different types of claimed or proven rights to land that may be exercised by Aboriginal people in Western Canada. The prairie provinces, portions of north-eastern British Columbia, small portions of Vancouver Island. and portions of the Northwest Territories are subject to historical treaties. Modern treaties or comprehensive land claim agreements have been finalized elsewhere, including portions of the Northwest Territories, Yukon, and British Columbia. In addition, other comprehensive land claim agreements are under negotiation in those areas.

In British Columbia, apart from that area covered by Treaty No. $8,{ }^{4}$ much of the province is subject to claims for Aboriginal title or Aboriginal rights. There have also been many new developments across the country in the law regarding the rights of Métis people.

Each of these different types of rights may lead to dillerent Crown obligations in relation to proposed projects or direct government regulation. As a result, it is important to understand the nature of these different rights, and where they may be encountered in Canada, in order to understand the obligations of the Crown in relation to consultation.

\section{A. TREATY RIGHTS}

Treaties are unique legal instruments entered into by the $\Lambda$ boriginal peoples of Canada and the Crown. Aboriginal treaties create positive rights for the adherent First Nations. The nature and content of the numerous treaties in Canada vary depending on the wording of the treaty, the historical context in which the treaty was negotiated and signed, and the purpose of the treaty. Common to all treaties is an intention to create legal obligations, the presence of mutually binding obligations, and a measure of solemnity. 5

Aboriginal treaties are an important part of Canadian history and extend back to the 18 th and 19 th centuries. Various treaties involving the Maritime Provinces and Ontario were entered into in the 1700 s and 1800 s. $^{.}$These treaties contain varying rights. For instance, the Treaty of 1752 contains guarantees of hunting rights. ${ }^{7}$ Some of the oldest treaties are "peace and friendship treaties" designed to ensure Aboriginal allegiance to the British Crown, and may not have referred to the extinguishment of Aboriginal rights or title.

- Canada. Treaty No. 8 Mude Jume 21, 1899 and Adhesions. Reports, Efc. (Ottawa: Quecn's Prinler. 1966), online: Indian and Northern Aflairs Canada (INAC) <www.ailuc-inac.ge.ca/pr/trts/trty8 c.htul> [Treaty No. 8].

R. I. Siomi, [1990] I S.C.R. I025.

In particular, examples include the New Brunswick and Nova Scotia Treaties of 1725, 1726, $1749,1752$. 1760, 1761, 1778, and 1779, and the Ontario Treaties ol 1790 and Treaty 20 in 1818 . Sec $R$. $v$. Paul (1998), 196 N.B.R. (2d) 292 (C.A.) for a discussion of the Truatics of 1725 and 1726.

The validity of the Treaty of 1752 was confirmed in the Supreme Court of Canada decision of $R$, $v$. Simon. [1985] 2 S.C.R. 387. 
Treaty rights under later historical treaties (particularly the numbered treaties) tended to consist of the Crown granting or assuring various rights to Aboriginal peoples in exchange for the extinguishment of Aboriginal title and related rights to land. For example, the following treaty provision exists in some form in all of the numbered treaties:

And Her Majesty the Quecn HERFBY ACjREES with the said Indians that they shall have the right to pursuc their usual vocations of hunting. trapping and fishing throughout the tract surrendered as heretofore described, subject to such regulations as may from time to time be made by the Govemment of the country. acting under the authority of Her Majesty, and saving and excepting such tracts as may be required or taken up from time to time for settlement, mining, lumbering, trading or other purposes.

It is important to note that treaties may take various forms and the written document representing a treaty may not contain all the treaty terms. In addition to the written terms, treaties may also contain oral terms. ${ }^{4}$

The numbered treaties in the prairie provinces were modified by the Natural Resources Transfer Agreements (NRTA). The NRTA, which were appended to the Constitution Act, $1930,{ }^{10}$ transferred Crown lands and natural resources from the federal government to the provincial governments of Manitoba, Alberta, and Saskatchewan. In $R$. v. Badger, the Supreme Court of Canada held that the NRTA modified but did not extinguish the Treaty No. 8 right to hunt in Alberta." First, it was held that the NRTA limited the purpose for which the hunting right could be exercised. While signatory First Nations could continue to hunt for food, they could no longer hunt commercially.'2 Second, it was held that the right was modified geographically. The signatory First Nations were no longer restricted to hunting within the Treaty No. 8 area, but could now hunt on "all unoccupied Crown lands and on any other lands to which the said Indians may have a right of access."

Over the past 25 years, the Supreme Court of Canada has developed fundamental principles of treaty interpretation. The most recent, comprehensive review of these principles by the Supreme Court is set out in its decision in Marshall. ${ }^{\text {t4 }}$ While a thorough review of these principles is beyond the scope of this article, it should be noted that historical treaty rights will always be interpreted liberally and in a sui generis manner, which takes into account the historical context under which the treaty was negotiated. This interpretive process is significantly different from the usual rules of contract interpretation. As such, caution should always be exercised when relying on the written terms of a treaty.

s Tran No. 8. supra note 4.

- Marshall v. Canoda. [1999] 3 S.C.R. 456 [Marshall], rehearing dismissed [1999] 3 S.C.R. 533.

10 Natural Resources Tramsfer Agreements, being Schedules to the Constitution Act. 1930 (U.K.), 20 \& 21 Geo. V, c. 26, s. 13, reprinted in R.S.C. 1985. App. II, No. 26. R. v. Badger, [1996] I S.C.R. 771 [Badger]. See also R. v. Horse, [1988] I S.C.R. 187 regurding the Saskatchewan NRTA and Treaty No. 6.

I: Badger, ibid, at para. 33. citing sitpra note 10 at para. 12.

1 Ibid. See also R. x. Horseman, [1990] 1 S.C.R. 901.

is Supra note 9 at para. 78 . 


\section{B. COMPREHENSIVF LAND CI,AIM AGREEMENTS}

Comprehensive land claim agreements differ significantly from historical treaties. Each comprehensive land claim agreement must be considered on its own terms, given the broad scope of the agreements and the fact that the language and terms in each agreement can be different.

In general, comprehensive land claim agreements are extensive and detailed agreements between an Aboriginal group and the Crown intended to resolve outstanding land claim issues. These agreements generally provide the Aboriginal group with ownership of large tracts of land, including subsurface title to some of the lands. They generally provide for participation in resource management and environmental review bodies and may include self-government provisions. In some cases, a separate agreement is entered into regarding self-government. As well, comprehensive land claim agreements may include specific consultation requirements that impose obligations on third parties seeking to do business or develop resources on the settlement lands. It is therefore important for a project proponent contemplating a project in an area covered by a comprehensive land claim agreement to understand the nature of the rights that may arise and the obligations and requirements imposed on third parties under the applicable agreement.

One of the better known examples of a completed comprehensive land claim agreement is the Sahtu Dene and Métis Comprehensive Land Claim Agreement. ${ }^{\text {s }}$ This agreement contains provisions on, among other things, land, access to land, natural resources, wildlife harvesting and management, harvesting compensation, resource royalties, and participation in land-use and environmental assessment bodies.

Additionally, numerous modern treaties are currently being negotiated between Aboriginal groups in British Columbia and the federal and provincial governments. " At present, six such instances of negotiation have led to the cxecution of Agreements in Principle. ${ }^{17}$

In addition to any fully executed comprehensive land claim agreements, there are many interim measures agreements or other agreements that have been reached by various British Columbia First Nations with the federal and/or provincial governments in relation to the use and/or management of Crown lands pending the conclusion of comprehensive land claim agreements. These interim agreements may include clauses regarding consultation or land and resource use and management that may impact resource development in certain areas. Care should be taken by project proponents to identify and understand the requirements of any such agreement.

1s See online: INAC <www.ainc-inac.ge.ca/pr/agr/sahtu/sahmel_c.pdf>.

10 For current updates on the various treaty negotiations, sec online: British Columbia Treaty Commission <www.bctrealy.netfiles_3/updates.html>.

1) The following Aboriginal groups lave execuled $A$ greements in Principle in the British Columbia treaty process: Lheidli T"enneh Band, Maa-nulth First Nations, Yale First Nation. Sliammon Indian Band, Tsawwassen First Nation, and Yekooche Nation. Copies of each of these agreements are available online: INAC <www,ainc-inac.gc.ca/pr/agr/index_c.htmI\#Agreements-In-Principle I>. 


\section{Aboriginal Rights}

Certain Aboriginal rights, such as hunting and fishing rights ${ }^{18}$ and the right of self-government, ${ }^{19}$ may exist independent of any treaty or comprehensive land claim agreement. The clearest judicial definition of Aboriginal rights was provided by the Supreme Court of Canada in the leading Aboriginal rights case of $R$. $v$. Van der Peet. ${ }^{20}$ In Van der Peet, the Court set out a basic defining test for establishing the existence of an Aboriginal right, as well as several factors to be considered in applying the test. The Court stated: "in order to be an aboriginal right an activity must be an element of a practice, custom or tradition integral to the distinctive culture of the aboriginal group claiming the right."

It is important to note that the existence of a particular right is fact-specific and is specific to the Aboriginal group claiming the right. Therefore, it is possible for one Aboriginal group to possess a particular right and for another Aboriginal group not to possess that same type of right.

To be integral to the distinctive culture of the Aboriginal group in question, the practice, custom, or tradition must be of central significance to that group and it must be such that it made the culture of the society distinctive. ${ }^{22}$ In addition, a claimant must establish that the practice, custom, or tradition that forms the basis of the right claimed existed prior to European contact. ${ }^{23}$ This aspect of the claim is based on one of the underlying principles of s. 35 of the Constitution Act, 1982. ${ }^{24}$ That is, s. 35 is an attempt to reconcile the existence of Aboriginal societies in Canada prior to sovereignty with the sovereignty of the Crown.

The Aboriginal claimant must also establish that the exercise of the practice, custom, or tradition has continued to the present in some form. The Aboriginal group need not exercise the right in precisely the form it existed prior to contact, but can exercise the right in its modern equivalent, so long as continuity is established. ${ }^{2 s}$

One of the best known, most common, and most publicized Aboriginal rights is the right to hunt or fish for sustenance purposes. In some cases, but not all, the Aboriginal group claiming this right may also be able to establish that hunting or fishing traditionally has had a commercial or trade aspect and, therefore, that there is an Aboriginal right to hunt or fish commercially. ${ }^{26}$

14 Camphell v. British Columbia (A.G.), 2000 BCSC 1123, 79 B.C.L.R. (3d) 122; add'I reasons in 2001 BCSC 1400.11 C.P.C. (5th) 384. For a decision where the evidence did not support a right to selfgovemment, see Twinn v. R., [1996] I F.C. 3 (T.D.), rev'd by Sawridge Band v. R., [1997] 3 F.C. 580 (C.A.) where a new trial was ordered based on the finding of reasonable apprehension of bias.

$\therefore \quad$ [1996] 2 S.C.R. 507 [Van der Peer].

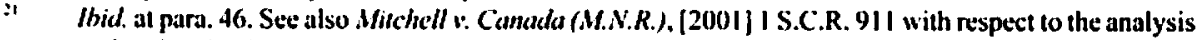
undertaken in characterizing the claimed Aboriginal right.

V'ais der Pect, ibid. at para. 55.

Ibid. al para. 60.

Heing Sclsedule B to the Camada Act 1982 (U.K.), 1982, c. 11.

V'an der Peet, supra note 20 at para. 64.

This issuc was considered in Van der Peet, ibid.; R. v. N.T.C. Smokehouse, [1996] 2 S.C.R. 672; and R. v. Gladstone, [1996] 2 S.C.R. 723 [Gladstone]. Only in Gladstone did the Supreme Court of Canada find that there was an historical and evidentiary basis for a right to trade in fish. 


\section{A boriginal. Title}

Aboriginal title is a form of Aboriginal right. However, it is a right in the land itself as opposed to a right to do, or participate in, a certain activity. It is a sui generis interest in land, meaning that it is unique unto itself and is distinguished from other forms of proprietary interests in land.

Aboriginal title arises from the fact that $A$ boriginal peoples were in Canada first. As stated by Judson J. in Calder v. British Columbia (A.G.): "the fact is that when the settlers came, the Indians were there, organized in societies and occupying the land as their forefathers had done for centuries. This is what Indian title means."27

Aboriginal title includes the right and title to the minerals and resources underlying the land. ${ }^{28}$ The most frequently cited definition of Aboriginal title was stated by Lamer C.J.C. in Delgamunkw:

I have arrived at the conclusion that the content of aboriginal tille can be summarized by two propositions: first, that aboriginal title encompasses the right to exclusive use and occupation of the land held pursuant to that title for a variety of purposes, which need not be aspects of those aboriginal practices, customs and traditions which are integral to distinctive aboriginal cultures; and second, that those protected uses must not be irreconcilable with the nature of the group's attachment to that land. ${ }^{29}$

The principle that uses to which the lands may be put are not to be irreconcilable with the nature of the group's attachment to the land is an inherent limit on Aboriginal title that derives from the fact that the historic use and occupancy of the land created an attachment to the land that, in turn, is an aspect of the society's distinctive culture. As such, the occupancy and attachment to the land are the very basis for the Aboriginal title. ${ }^{30}$ Chief Justice Lamer provided two examples of irreconcilable uses of land: (1) lands traditionally used as hunting grounds cannot have been used in such a fashion so as to destroy their use as hunting grounds (e.g., strip mining); and (2) ceremonial lands cannot be destroyed to build a parking lot and thereby destroy their ceremonial or cultural significance."

Aboriginal title is also unique and distinct from other proprietary interests in land in that there are restrictions on its alienability. In most cases, a title holder can sell, lease, or dispose of its interest in land as, and to whom, it chooses. By contrast, an Aboriginal group with Aboriginal title cannot transfer, sell, or lease the land except as allowed by statute and then only to the Crown. ${ }^{32}$ This includes lease of mineral and resource rights that are part of Aboriginal title.

[1973] S.C.R. 313 at 328. See also Delgammokw v. British Colomina, |1997| 3 S.C.R. 1010 at para. 114 [Delgamuakw]. 
Additionally, like Aboriginal rights in general, Aboriginal title is a collective right held by a First Nation and not by individual members of the group. ${ }^{33}$ As such, it does not provide individual Aboriginal persons with title to any particular lands. As with Aboriginal rights, the group claiming Aboriginal title has the onus of proving title.

In a recent Supreme Court of Canada decision that addresses the test for $A$ boriginal title, ${ }^{34}$ the Court examined the standard of occupancy required to prove a successful Aboriginal title claim, including the related issues of exclusivity of occupation, application of this requirement to nomadic peoples, and continuity. ${ }^{35}$

With respect to the concept of exclusivity, the Court stated that a claimant must be able to establish evidence of "sufficiently regular and exclusive" use of the particular portion of land in question (prior to European contact) as demonstrated by an "intention and capacity to retain exclusive control" of that portion of land. ${ }^{36}$ The Court further noted that the right to control the land and, if necessary, to exclude others from using it, is basic to the notion of title at common law. However, it was held that the question of exclusion must also be viewed from the Aboriginal perspective. ${ }^{37}$ Moreover, the Court held that evidence of acts of exclusion is not required to establish Aboriginal title. All that is required is demonstration of effective control of the land by the group, from which a reasonable inference can be drawn that it could have excluded others had it chosen to do so. The fact that history, insofar as it can be ascertained, discloses no adverse claimants may support this inference. The Court held that this is what is meant by the requirement that the lands have been occupied in an exclusive manner. ${ }^{38}$

In addressing the issue of whether nomadic and semi-nomadic peoples can ever claim title to Aboriginal land, as distinguished from rights to use the land in traditional ways, the Court found that it depends on the evidence. Whether a nomadic people enjoyed sufficient "physical possession" to give them title to the land is a question of fact depending on all the circumstances, in particular the nature of the land and the manner in which it is commonly used. In each case, the question is whether a degree of physical occupation or use equivalent to common law title has been made out. ${ }^{39}$

Lastly, the Court addressed the issue of continuity. The requirement of continuity in its most basic sense simply means that claimants must establish that they are right holders. Modern-day claimants must establish a connection with the pre-sovereignty group upon whose practices they rely to assert title or claim to a more restricted Aboriginal right. The right is based on pre-sovereignty Aboriginal practices. To advance the claim, a modern people must show that the right is the descendant of those practices. Continuity may also be raised in this sense. To claim title, the group's connection with the land must be shown to

Bbid. at para. 115.

R. v. Bernard, $2005 \mathrm{SCC} 43,[2005] 2$ S.C.R. 220.

ibiel.

Ibid. at paras. 58,57 , respectively.

bid. al para. 64.

Ihid.

Ibid. at para. 66. 
have been "of a central significance to their distinctive culture." If If the group has "maintained a substantial connection" with the land since sovereignty, this establishes the required "central significance."

In general terms, to prove Aboriginal title, a claimant must establish that:

(a) it occupied the applicable land prior to sovereignty;

(b) at sovereignty, its occupation was exclusive, ${ }^{42}$ and

(c) it has maintained a "substantial connection" with the land since sovereignty.

While the test for establishing Aboriginal title has now been established by the Supreme Court of Canada, we are not aware of any reported decisions that apply the test and reach a determination of the existence of Aboriginal title in a particular area.

In British Columbia, in addition to recognition through the process of litigation, Aboriginal title will be recognized and defined through modern treaties.

\section{E. Métis Rights}

The Métis culture developed initially as a result of unions between Europeans and Native Canadians during the colonial period. The Métis of Canada consist of numerous distinct communities that "share the common experience of having forged a new culture." The Supreme Court of Canada has noted that this culture is "not reducible to the mere fact of their mixed ancestry" and that "[w]hat distinguishes Métis people from everyone clse is that they associate themselves with a culture that is distinctly Métis." "th Furthermore, the Supreme Court has defined a Métis community as "a group of Métis with a distinctive collective identity, living together in the same geographic area and sharing a common way of life."

The rights of the Métis are explicitly protected under s. 35 of the Constintion Act, 1982, , as Métis people are included in the definition of "Aboriginal peoples of Canada." Therefore, to the extent that Métis enjoy Aboriginal rights, those rights are constitutionally protected. However, in comparison to the Aboriginal rights of First Nations people, there has been little jurisprudence dealing with the scope, nature, or extent of Metis rights. One notable and leading decision in this area is Powley." which was released by the Supreme Court of Canada in September 2003, and involved a finding that a Métis community near Sault Ste.

lbid. at para. 67, citing $R$. v: Adams, [1996] 3 S.C.R. 101 at para. 26.

Ibid., citing Delgamumki, supra note 27 at paras. $150-51$.

Note that a practice of "shared exclusivity" of possession, such as where two Aboriginal groups lived on the same portion of land. may also suffice to establish the requisite levels of occupancy. Set Delgammukw, ibid. at paras. $58,158$.

R. v. Pow/ly, 2003 SCC 43. [2003] 2 S.C.R. 207 al para. II [rowkey].

lbid. al para. 10.

lhid. al para. 12.

Supra note 24.

Supra note 43. Sec also R. v: Blais, 2003 SCC 44. [2003] 2 S.C.R. 236. where the Supreme Court of Canada declined to find that the term "Indian" included a Métis person secking rights expressly provided to "Indians" under the Manitoba NRTA. Onc elfect of this decision is that Metis do not have the right. as certain Treaty Indians do, to hunt or fish on any unoccupied Crown lands by virtuc of the NRTA. 
Marie, Ontario hoids a constitutionally-protected Aboriginal right to hunt for food in areas near Sault Ste Marie.

Although Aboriginal rights jurisprudence is applicable in the Métis context, the interpretation of Aboriginal rights has evolved in such a manner that it is inherently inapplicable to the Métis. As stated above, under the test in $\operatorname{Van} \operatorname{der} P e e f^{48}$ the claimant of an Aboriginal right must show that the right existed prior to European contact. Such a requirement is impossible in the Metis context since the culture developed within the circumstances of, and after, contact. Therefore, the Ontario Court of Appeal and the Supreme Court of Canada in Powley articulated a modified version of the Van der Peet test to accommodate the Métis context and "reflect the distinctive history and post-contact ethnogenesis of the Métis, and the resulting differences between Indian claims and Métis claims." ${ }^{.49}$ The Supreme Court stated:

We accept Van der Peet as the template for this discussion. However, we modily the pre-contact focus of the $V$ on der Peet test when the claimants are Métis to account for the important differences between Indian and Mitis claims. Section 35 requires that we recognize and protect those customs and traditions that were historically important fealures ol' Métis communities prior to the rime of effective European control, and that persist in the present day. This modification is required to account for the unique post-contact emergence of Métis communities, and the post-contact foundation of their aboriginal rights.

More specifically, the Court held:

This unique history [of the Mćtis] can most appropriately be aceommodated by a post-contact but pre-control test that identifies the time when Europeans effectively established political and legal control in a particular area. The focus should be on the period affer a particutar Métis communily arose and before it came under the effective control of European laws and customs. This pre-control test enables us to identify those practices, customs and traditions that predate the imposition of European laws and customs on the Métis. ${ }^{51}$

It was stated in Powley that "the existence of an identifiable Métis community must be demonstrated with some degree of continuity and stability in order to support a site-specific aboriginal rights claim." 52 Furthermore, the right claimed must be shown to have been practiced continuously by that community from the time Europeans effectively established political and legal control over the particular area to the present. ${ }^{53}$

Another important issue that confronts courts in Métis rights claims is the definition of individual Métis claimants. The Supreme Court of Canada stated in Powley that when an individual claimant seeks recognition of rights based upon his or her Métis identity, a court is to address "three broad factors as indicia" in determining the existence of such identity: (1) self-identification as a member of a contemporary Métis community; (2) an ancestral 
connection to a historic Métis community; and (3) acceptance by the contemporary Métis community. ${ }^{54}$

While the law regarding Métis rights is not fully developed, ${ }^{55}$ it is evident that courts will seek to hold Métis rights as deserving of a similar level of protection as other Aboriginal rights. Indeed, both the Sparron ${ }^{56}$ and Haida/Taku River/Mikisew ${ }^{57}$ tests (examined below). which assess when a given infringement of an Aboriginal right may be justified, have been adopted in the Métis context. ${ }^{s \&}$

\section{The Common Law Duty to Consult and Accommodate}

Section 35 of the Constimution Act, 1982 provides constitutional protection of Aboriginal and treaty rights: "The existing aboriginal and treaty rights of the aboriginal peoples of Canada are hereby recognized and affirmed." ${ }^{\circ 9}$ However, the constitutional protection of Aboriginal and treaty rights does not mean that those rights are absolute. The Supreme Court of Canada has repeatedly indicated that in certain circumstances the Crown may infringe both proven and asserted $A$ boriginal rights. With respect to infringement of Aboriginal rights through direct government regulation, the Supreme Court set out a specific justification test in its 1990 decision in Sparrow. ${ }^{\text {(t) }}$ With respect to infringement of Aboriginal rights through other types of government action such as the issuance of land-use approvals, the Supreme Court of Canada more recently set out a different form of justification test in Haida, Taku River, and Mikisew. Both tests include, to varying degrees, a requirement for consultation with Aboriginal people regarding their interests, prior to infringement.

In cases involving an infringement of a proven Aboriginal or treaty right, the source of the Crown's obligation to consult and, where indicated, to accommodate such interests is traceable to the fact that such interests are constitutionally protected. Additionally, when historical treaties are at stake, the Supreme Court of Canada has stated that Aboriginal signatories to such treaties actually have positive "procedural" treaty rights to be honourably consulted. ${ }^{61}$ On the other hand, in cases involving an infringement of an asserted but not yet proven Aboriginal interest, the source of the Crown's applicable obligations of consultation

$4 \quad$ bid. at para. 30.

" For notable examples of some recent lower court decisions that have applied the principles espoused in Powley, see R. v. Laviolente, 2005 SKPC 70, 267 Sask. R. 291; R. v. II'illisem, 2005 BCPC 131. [2005] 3C.N.L.R. 278; and Labrador Metis Nation v. Newfoundlandandlabrador (Minister of Transportation and Works), 2006 NLTD 119, 258 NIld. \& P.E.I.R. 257 [Labrador Metis Nation]. Supra nole 18.

s: Supra noles 1-3.

¿ The Sparrow test is adopted in Powley. supro note 43 at para. 48 , and the Haida test is adopted in labrador Mefis Nallow, supra note 55 at para. 93.

Supra note 24, s. 35.

* Supra note 18 at para. 62. Nole also that leave to appeal has been granted in relation to two separate decisions of the Alberta Cour of Queen's Bench: $R$. v. Eagle Child, 2005 A $13 Q 13$ 225, 383 A.R. 169 and R. v. Lefhomd, 2005 ABQB 748, 388 A.R. 231 (leave lo appeal granted in botl cases. 2006 ABCA 70). Both cases address the requirements ler consultation and accommodation prior to the implementation of direct government regulation of a treaty fishing right. See also $R$. v. Hanclin. 2006 ABPC 12, [2006] 2 C.N.L.R. 171. 
and accommodation, as discussed in more detail below, ${ }^{62}$ is the honour of the Crown, which is "always at stake in its dealings with Aboriginal peoples."

Although the Sparrow decision relates to infringements of Aboriginal interests through direct government regulation as opposed to infringements through environmental assessment or project decisions involving industry (the latter being the focus of this article), its pronouncements serve as an important backdrop to an analysis of the more recent judicial pronouncements in relation to the latter types of infringements. As such, the decision in Sparrow is considered below.

\section{A. R. V. SPARROW}

In Sparrow, the accused, a member of the Musqueam Indian Band, was charged with fishing with a longer net than permitted by the Band's food fishing licence, which was issued pursuant to the provisions of the federal Fisheries $A c t^{\phi 5}$ and regulations. The accused admitted the facts that formed the basis of the charge but defended on the basis that he had an Aboriginal right to lish and that the limitations in the licence and the Fisheries Act infringed his right and were therefore invalid.

Having concluded that the claimant possessed an Aboriginal right to fish for food, the Court went on to consider whether the right was protected by s. 35(1) of the Constitution Act, 1982 and to what extent. The Court confirmed that Aboriginal rights, though protected by s. 35, are not absolute and may be infringed where the infringement is justified. The test for infringement involves several stages:

(a) Does the legislation or government action lead to a prima facie infringement of an existing Aboriginal right? ?th $^{\text {th }}$

(b) Is the infringement justified?

(i) Is there a valid legislative objective? ${ }^{67}$

(ii) Has the honour of the Crown been upheld? Factors to be considered include:68

- Has priority in the allocation of the resource been given to the First Nation?

- Has there been as little infringement as possible in order to effect the desired result?

- In a situation of expropriation, is fair compensation available?

- Has the Aboriginal group in question been consulted?

62 See infra note 86 and surrounding text.

A) Haida, supra nole 1 at para. 16.

is Supra nole 18.

63 R.S.C. 1985, c. 1. 14 .

hr

Spurrow, suppru note 18 at para. 68.

lbid. at para. 71.

Ibid. at para. 82.

In Gladstone, supra note 26 at para. 54, the Supreme Court of Canada characterized the Sporrow test as a two-part lest: (1) "the govemment must demonstrate that it acted pursuant to a valid legislative objective"; and (2) "the government must demonstrate that its actions are consistent with the fiduciary duty of the govemment towards aboriginal peoples." 
The onus is on the Aboriginal right claimants to show the prima facie infringement of an Aboriginal right. Canadian courts generally have applied a low threshold when determining the existence of a primaifacie infringement. ${ }^{70} \mathrm{~A}$ court will consider various factors at this stage of the analysis including whether:

(a) the limitation is reasonable;

(b) the regulation imposes undue hardship; and

(c) the regulation denies the Aboriginal right-holders their preferred means of exercising the right. ${ }^{71}$

Once a prima facie infringement has been shown, the onus shifts to the Crown to show that there is a valid legislative objective underlying the impugned statute or regulation. A valid legislative objective has been interpreted broadly, and has been held to include

the development of agriculture, forests, mining, and hydroclectric powst, the general economic development of the interior of British Columbia, protection of the environment or endangered species, the building of infrastructure and the settlement of foreign populations to support those aims. ${ }^{72}$

If a valid legislative objective exists, the court will then consider whether the honour of the Crown has been upheld. This is where the consultation issue is considered in instances of infringement of Aboriginal interests through direct government regulation.

Courts that have applied the Sparrow' test have generally placed more emphasis on priority and minimal infringement than on consultation with Aboriginal peoples. More recently, the justification test espoused in Sparrow has been redefined to address instances of infringement of Aboriginal interests through project approval decisions by governinent agencies or regulatory bodies. In Haida, Taku River, and Mikisew, the Supreme Court of Canada has placed far greater emphasis on consultation in articulating the analysis that relates to this latter type of infringement, establishing a general framework for Crown obligations to consult and, where indicated, to accommodate Aboriginal interests before making project approval decisions that may infringe those interests.

\section{B. HAIDA NATION V. BRITISH COLUMBIA (MINISTER OF FORESTS)}

In Haida, the Haida Nation (the Haida) had claimed Aboriginal title to the lands of Haida Gwaii (also known as the Queen Charlotte Islands) and the surrounding waters, which claim had not been (and has not been) legally recognized. The Haida has never signed a treaty nor surrendered its interests in land. In 1961, the British Columbia Ministry of Forests granted Tree Farm License 39 (TFL) to MacMillan Bloedel, which permitted harvesting trees in portions of Haida Gwaii. Over time, the TFL was replaced and ultimately transferred to Weyerhaeuser in 2000. 
The Haida brought a judicial review application seeking a declaration that the replacements and the transfer to Weyerhaeuser be set aside on the basis that the Crown could not validly issue the replacements on land encumbered by Aboriginal title or to which Aboriginal title is claimed. The issue of whether the Haida have Aboriginal title to the land in question was deferred to trial, but the judicial review application proceeded on the question of whether adequate consultation had occurred prior to the issuance of the TFL replacements.

The chambers judge dismissed the petition and held that the government had a moral duty to negotiate, but did not have a legal or equitable duty of consultation because the duty of consultation only arises in the face of proven, and not merely asserted, Aboriginal rights and title. $^{73}$

The British Columbia Court of Appeal unanimously reversed the chambers judge's decision and held that the duty to consult arises even where there is an asserted but not yet proven claim to Aboriginal title, and that the Crown had not fulfilled its duty to consult prior to issuing the replacements. ${ }^{74}$ The Court did not quash those replacements, but rather ordered that both the Crown and the project proponent consult with the Haida and "seck to accommodate" the Haida interests that had been affected in this matter.

As an aside, the declarations in relation to separate obligations owed by project proponents came as a surprise, as that issue had not been put forward by counsel in the hearing of the application, nor contemplated in previous decisions. As a result, after the decision was released, counsel sought and were granted leave to return to the Court to argue the separate issuc of whether the project proponent owed independent obligations to Aboriginal peoples.

In a second decision released by the Court of Appeal, ${ }^{75}$ the Court was not unanimous. Each of the three judges hearing the appeal released separate reasons. Justice Lambert, who had written the first decision, found three bases for an independent obligation of the project proponent: (1) the legislation governing forestry activities; ${ }^{76}(2)$ the fact that in this case the project proponent knew or ought to have known that the original licence was issued in breach of the Crown's obligation to consult with the Haida, and that it was therefore in "knowing receipt" of an authorization with a fundamental legal defect and had become a constructive trustee, owing a third-party fiduciary duty to the Haida;" and (3) the fact that the forestry scheme in this instance granted the project proponent control over day-to-day decisions that impact Haida interests and that, therefore, the legal test for justification of the infringement of Aboriginal rights (including the obligation to consult) should apply to such decisions. ${ }^{78}$

Haida Nation v. British Cohmbin (Minister of Foresss), 2001 BCSC 1280, [2001] 2 C.N.1.R. 83.

Ilatidu Nation b. British Columbiu (Mfinisler of Fores/s), 2002 BCCA 147, 99 B.C.L.R. (3d) 209.

" Haida Nation b. British Columbia (Mfinister of Forests), 2002 BCCA 462, 5 B.C.L.R. (4th) 33 [Haida III.

io lbid. al para. 60.

Ihid. at para. 72.

is lbid. at para. 93. 
Chief Justice Finch agreed in the result with Lambert J.A., but for different reasons. In his view, it was necessary for the Court to order the project proponent to consult with and to seek to accommodate the Haida in the circumstances of this case because of the fact that the remedy ordered by the Court did not involve quashing the replacements of the TFL. Moreover, he held that a declaration that the Crown has obligations to consult, without more. would be "completely hollow" because without the participation of the project proponent. the Crown would be effectively unable to make any decisions regarding the accommodation of the applicable Haida interests. ${ }^{79}$ Notably, he also stated that such accommodation would likely include employment and contracting opportunities. ${ }^{80}$

Justice Low dissented, stating that the Haida had established no basis in law for a mandatory order against the project proponent. ${ }^{81}$

The Supreme Court of Canada ultimately dismissed the Crown's appeal and confirmed that the duty to consult arises even where there is an asserted but not yet proven claim to an Aboriginal interest. ${ }^{{ }^{2}}$ However, it held that project proponents cannot be held liable for failing to discharge the Crown's duty to consult and accommodate. ${ }^{{ }^{3} 3}$ Speaking for a unanimous court, McLachlin C.J.C. stated that the Crown may delegate procedural aspects of consultation to project proponents, ${ }^{, 4}$ but that the honour of the Crown itself cannot be delegated, and that the Crown alone remains legally responsible for the consequences of its actions and interactions with project proponents that affect Aboriginal interests. It was noted that project proponents can still be liable to Aboriginal peoples in the usual course at common law where they are negligent, in breach of contractual obligations, or have been found to have been dealing dishonestly. ${ }^{85}$

Chief Justice McLachlin stated that the source of the duty to consult and, where indicated, to accommodate is grounded in the honour of the Crown $\mathrm{n}^{\mathrm{ks}}$ and that the duty itself is "part of a process of fair dealing and reconciliation that begins with the assertion of sovereignty and continues beyond formal claims resolution." 87 It was held that although fiduciary responsibilities were not owed by the Crown to the Haida in this instance (since the interest was merely asserted but not yet proven), it is a corollary of s. 35 of the Constitution Act, $1982^{88}$ that the Crown act honourably in defining the rights it guarantees and in reconciling those rights with other rights and interests."

Chief Justice McLachlin stated that the duty to consult ultimately arises when the Crown has knowledge, real or constructive, of the potential existence of the Aboriginal right or title

is $\quad$ bid. at para. 118.

so $\quad$ bid. at para. 119.

"Ibid. at para. 131.

s. Haida. stupra note 1 .

ki loid. at para. 53.

Rt Ibid.

35 Ihid. at para. 56.

so libid. at para. 16.

s) Ibid. at para. 32.

kx Supra note 24.

$89 \quad$ Haida, supra note 1 at para. 38. 
and contemplates conduct that might adversely affect it. ${ }^{\% 0}$ In order to help ensure that the Crown obtains such knowledge, it was held that there is an expectation of Aboriginal claimants to come forward and "outline their claims with clarity, focusing on the scope and nature of the Aboriginal rights they assert and on the alleged infringements. ${ }^{* 91}$

The Supreme Court of Canada held that the scope and content of the required duty will vary with the circumstances of a given case, ultimately falling somewhere on a spectrum depending upon a preliminary assessment of: (1) the strength of the case supporting the existence of the right or title; and (2) the seriousness of the potentially adverse effect upon the right or title claimed. ${ }^{12}$ A dubious or peripheral claim will require less consultation than a strong claim. At one end of the spectrum, where there is only a dubious claim to a particular right and where the potential infringement is minor, the duty may be limited to giving notice, disclosing information and discussing concerns of a particular Aboriginal group with that group. ${ }^{93}$ At the other end of the spectrum, where there is a strong claim for a particular right and the risk of non-compensable impact to the exercise and enjoyment of that right is high, then "deep consultation" will be required. ${ }^{94}$ A process of "deep consultation" was described by McLachlin C.J.C. as one that "may entail the opportunity [ for the Aboriginal group] to make submissions for consideration, formal participation in the decision-making process, and provision of written reasons to show that Aboriginal concerns were considered and to reveal the impact they had on the decision. ${ }^{\text {nos }}$

The Crown is not under a duty to reach an agreement with an Aboriginal group asserting the existence of an unproven interest. Rather, the extent of the obligation is that it engage in a meaningful process of consultation in good faith." An Aboriginal group asserting an as-yet unproven interest will not hold a veto over land-use decisions made by the Crown. ${ }^{17}$

The Aboriginal claimants must also act in good faith. ${ }^{9 *}$ Aboriginal claimants must not frustrate the Crown's reasonable good faith attempts to consult, nor take unreasonable

bid. at pars. 64.

lbid. at para. 36.

thid. at para. 39.

lbid. at para. 43.

Ibid. at para. 44.

lbid.

Ibid. at para. 42. Note that in the recent decision of Platinex Inc. v. Kitchenuhmaykoosib Inninmug First Nation, [2006] 4 C.N.L.R. 152 at para. 91 (Ont. Sup. Ct. J.) [Platinex], G.P. Smith J. of the Ontario Superior Court of Justice scems to take this a step further when stating that "[t]o be meaningful, the Crown must make good faith effors wo negotiate an agreemen" [emphasis added]. We do not fecl this statement accurately reflects the law. The applicable duty is to consult and, only if indicated through the process of consultation (but not until then), to accommodate, perhaps by making good faith efforts to negotiate an agreement. There is no aulomal ic duty lo make good faith efforts to negoliate an agreement. It is unclear whether or nol an Aboriginal group with a proven Aboriginal title right could hold an outright veto over a land-use decision. Note that Lamer C.J.C. stated, in his discussion of consultation duties in Detgommokw', supra note 27 at para. 168, that "[s]ome cases may even require the full consemt of an aboriginal nation." Notc also that in Mikisew, supra note 3 at para. 66, it was noted that parties to an historical treaty that have rights to hunt and fish that may be impacted by a particular land-use decision will not hold a veto over that decision.

Haida, supra note I at para. 42 . 
positions to thwart government from making decisions or acting in cases where, despite meaningful consultation, agreement is not reached. ${ }^{\text {ty }}$

The controlling question in all situations is what is required to maintain the honour of the Crown and to effect reconciliation between the Crown and the Aboriginal people with respect to the interests at stake. ${ }^{100}$

It was confirmed in Haida that good faith consultation may trigger a duty to accommodate. Chief Justice McLachlin stated that accommodation begins when the consultation process suggests amending Crown policy, ${ }^{101}$ and that where a strong prima facie case exists in support of a claimed right and significant adverse effects on that right are anticipated, steps may be required to avoid or to minimize the ultimate effects of infringement, pending resolution of an underlying claim. Furthermore, she expressly stated that any accommodation that may be indicated as a result of the consultation process will involve "seeking compromise in an attempt to harmonize conflicting interests." that while this notion of compromise requires a commitment to the process of reconciliation, it does not necessitate an agreement between the parties. ${ }^{103}$ Rather, it entails balancing Aboriginal concerns "reasonably with the potential impact of the decision on the asserted right or title and with other societal interests."104

Additionally, the Supreme Court of Canada confirmed that the duty to consult and, where indicated, to accommodate applies to the provincial governments as well as the federal government. ${ }^{105}$

The Chief Justice then applied the foregoing principles to the facts of this particular case and found that the Province of British Columbia had knowledge of the potential existence of Haida rights and title and made decisions that may have adversely affected those rights and that, therefore, the honour of the Crown mandated consultation prior to making the decisions. It was held that the strength of the case for Haida title and a Haida right to harvest trees suggested that the honour of the Crown may have required "significant accommodation" to preserve the Haida interest pending resolution of its claim. ${ }^{106}$ The Supreme Court of Canada found that the Province of British Columbia failed to engage in any meaningful consultation with the Haida and, therefore, failed to satisfy its obligations.

Although it was stated that "significant" accommodation may have been required in this instance, the Supreme Court of Canada did not give any indication of what such accommodation might entail. Unlike the British Columbia Court of Appeal, which had stated that employment and business opportunities would likely form a part of any practical 
accommodation of the Haida interests, ${ }^{107}$ the Supreme Court of Canada made no such reference, instead seeming to place more emphasis on the importance of efforts to "preserve" Haida interests and to minimize adverse effects pending final resolution of its claim. ${ }^{108}$

It is important to note that the only amendment the Supreme Court of Canada made to the Order granted by the British Columbia Court of Appeal was to the effect that the Crown alone, and not the project proponent, was directed to consult with and, where indicated, to accommodate Haida interests. That is, the applicable TFL replacements were not quashed.

\section{TAKU RIVER TLINGIT FIRST NATION V. BRITISH COLUMBIA (PROJECT ASSESSMENT DIRECTOR)}

The decision in Taku River, ${ }^{109}$ also written by the Chief Justice of the Supreme Court of Canada and released the same day as Haida, must also be examined in order to understand fully the current state of the law in regard to Crown obligations of consultation and accommodation in these types of scenarios. The Taku River decision illustrates the reality of certain limits on these obligations.

Taku River involved the proposed re-opening of a mine in northern British Columbia and the associated construction of an access road. Redfern, the project proponent in this matter, sought the applicable approval in 1994 under environmental assessment legislation in force at that time. ${ }^{110}$ That legislation included a requirement that a committee (the Project Committee) be established to provide expertise, analysis, advice, and recommendations to the Crown. Several groups having an interest in the project, including local Aboriginal groups, were invited to appoint representatives to the Project Committee.

The access road was routed across a portion of the traditional territory of the Taku River Tlingit First Nation (the Tlingit). The Tlingit were therefore invited to and did appoint a representative to the Project Committee. The Tlingit were also directly involved in a number of working groups and technical subcommittees that formed a part of the environmental assessment process.

As part of the environmental assessment process, the project proponent was required to produce a project report detailing various aspects of the project and its anticipated effects. After it issued its first report, the project proponent was then required to address certain deficiencies therein. At the same time, the Environmental Assessment Office(EAO) engaged a consultant approved by the Tlingit to conduct a traditional use study. The Tlingit were not satisfied with the study that was produced and, as a result, the consultant was retained a second time and an addendum to the study was produced.

Approximately three years after the filing of the project application, a final project report was prepared by EAO staff, which recommended that the project be approved subject to

\footnotetext{
(11): Ilsida II, supra note 75 at para. 119.

la: Haida, supra note 1 at para. 77.

Ior Supra note 2.

110 That legislation was subsequently replaced by the current Environmental Assessmem Act, S.B.C. 2002 , s. 43 [BCEA $]$, which came into effect in December 2002.
} 
certain conditions. Although the Tlingit refused to sign off on the report and, in fact, issued a minority report, the Minister ultimately decided to approve the project without an order for a public hearing.

The Tlingit had repeatedly expressed concerns that the project would adversely affect aspects of its culture, wildlife habitat in the area, and its ongoing treaty negotiations. Among other concerns, it felt that there was a lack of adequate baseline information by which to measure subsequent effects of the project. The Tlingit argued that the road should not be approved in the absence of a completed land use strategy and in any manner disconnected with the Tlingit's ongoing treaty negotiations.

The Tlingit ultimately sought judicial review of the Minister's decision to approve the project. The British Columbia Supreme Court held that the concerns of the Tlingit had not been meaningfully addressed during the consultation and accommodation processes, and the chambers judge quashed the project approval, referring it back to the Minister for reconsideration with a direction to address meaningfully the concerns of the Tlingit."'I

The Crown appealed that decision and a majority of the British Columbia Court of Appeal determined that the Crown did in fact owe a duty to consult the Tlingit and that it had not satisfied this duty in the circumstances of this case. "2 The chambers judge's decision to remit the matter to the Minister for reconsideration was upheld. The Crown then appealed that decision to the Supreme Court of Canada.

Applying the principles it first set out in Haida, the Supreme Court of Canada found that in this instance, the Crown had knowledge of the Tlingit claim to Aboriginal rights and title in relation to the particular area (as it was engaged with the Tlingit in a formal treaty negotiation process), and that it was conceivable that the project could adversely impact the Tlingit's traditional land use activities. Therefore, McLachlin C.J.C., again writing for a unanimous Court, stated that the obligation to consult and, if indicated, to accommodate was triggered.

Ultimately, however, it was held that in this particular instance, the Crown had provided a satisfactory measure of accommodation with respect to the applicable Tlingit interests. Chief Justice McLachlin found that the Tlingit had participated to a significant degree in the environmental assessment process and that its concerns had been meaningfully addressed. ${ }^{113}$ It was noted that the Project Committee had identified the Tlingit concerns and had recommended ongoing mitigation and accommodation strategies, including the collection of further baseline information, all of which had been adopted into the terms and conditions of the approval. 114

Taku River Tlingil First Nation :. British Cohumiba (P'roject Asse'ssmem Director), 2000 BCSC 1001 , 77 B.C.L.R. (3d) 310.

12. Taku River Tlingil First Nation v. British Cohumbia (I'roject Assessment Director), 2002 BCCA 59, 98 B.C.L.R. (3d) 16 .

113 Sippra note 2 al paras. 22, 34, 46, and 47.

114 ibid. at para. 46. 
Specifically, the Supreme Court of Canada stated that "[t]he Province was not required to develop special consultation measures to address [Tlingit] concerns, outside of the process provided for by the Environmental Assessment Act, which specifically set out a scheme that required consultation with affected Aboriginal peoples." 115

Ultimately, this decision may now serve as a benchmark or template as one instance of a successful discharge of Crown duties to consult and accommodate Aboriginal interests, albeit in the context of British Columbia's former environmental assessment legislation.

\section{MIKISEW CREE FIRST NATION V. CANADA (MINISTER OF CANADIAN HERITAGE)}

In the fall of 2005, the Supreme Court of Canada released its third recent significant decision addressing the nature and content of the Crown's duties of consultation and accommodation. In Mikisew, ${ }^{116}$ the Supreme Court of Canada examined consultation and accommodation duties in the context of historical treaty rights. The specific question in this case was whether the Crown had sufficiently consulted with the Mikisew Cree First Nation (the Mikisew) (a signatory to Trealy No. $8^{117}$ ) before approving the construction of a winter road through Wood Buffalo National Park (WBNP) that, if implemented, would traverse the trap lines of 14 Mikisew families.

The WBNP covers a significant portion of land $\left(44,807 \mathrm{~km}^{2}\right)$ straddling the boundary between northern Alberta and southern portion of the Northwest Territories. The park is located wholly within Trealy No. 8 territory. The Mikisew have reserve lands that are located within the park boundaries but which do not constitute part of the WBNP.

Treaty No. 8 was negotiated in 1899 and involved the surrender to the Crown of some $840,000 \mathrm{~km}^{2}$ of what is now northern Alberta, north-eastern British Columbia, north-western Saskatchewan, and a southern portion of the Northwest Territories. As noted above, one of the rights obtained by the First Nations (including the Mikisew) in exchange for this surrender was the right to pursuc their traditional vocations of hunting, trapping, and fishing on surrendered lands subject to certain conditions and "saving and excepting such tracts as may be required or taken up from time to time for settlement, mining, lumbering, trading or other purposes." 118

In May 2001, it was announced that the Minister of Canadian Heritage had approved the construction of a winter road in the WBNP that would track a portion of the boundary of the Mikisew reserve. The project would create a $200 \mathrm{~m}$ wide corridor, pursuant to the Wood Buffalo National Park Game Regulations, ${ }^{119}$ within which the use of firearms would be prohibited. In total, if the road were to be constructed, the Mikisew would lose the right to hunt approximately $23 \mathrm{~km}^{2}$ of traditional territory. The Mikisew argued that the project would also result in the fragmentation of wildlife habitat, disruption of migration patterns, 
loss of vegetation, increased poaching, and increased wildlife mortality caused by motor vehicle accidents.

Prior to approving the construction of the road, the Crown provided the Mikisew with a standard package of information about the project (the same package that was publicly distributed to all interested stakeholders). Parks Canada also held public, open-house sessions of which the Mikisew were advised. However, the Mikisew did not altend those sessions.

The original plan for the road saw the proposed route run directly through the Mikisew reserve. The Mikisew had sent two letters to Parks Canada stating its objection to the project. Parks Canada did not respond to the first of these letters and to the second provided only a standard-form response stating that the Mikisew objection "will be given every consideration." Parks Canada, in coordination with the project proponent, then re-aligned the proposed route of the road (in response to the objections of the Mikisew) so that it would not run directly through the Mikisew reserve, but would instead merely track its boundary. The road approval was then granted without any lurther consultation with the Mikisew. On 30 April 2001, the Chief of the Mikisew received a letter from Parks Canada stating, in part: "I apologize to you and your people for the way in which the consultation process unfolded." 20

After learning that the construction of the road had been approved, the Mikisew sought judicial review of the ministerial decision. The judicial review application was successful and the ministerial approval set aside. The trial judge held that the decision to approve the road was an unjustifiable infringement of the Mikisew's treaty rights to hunt and trap. The Federal Court of Appeal overturned this decision, however, accepting the novel argument put forward by the Province of Alberta that Treaty No. 8 expressly contemplates the Crown "taking up" surrendered lands and that the ministerial approval here was simply an instance of the Crown exercising its own treaty right as opposed to infringing any treaty rights of the Mikisew.

In a unanimous decision written by Binnie J., the Supreme Court of Canada ultimately recognized that the Crown indeed holds a positive treaty right (that exists in some form in all of the numbered treaties) to "take up" surrendered lands for a variety of purposes with the effect that certain treaty First Nations will be precluded from exercising their rights to hunt, trap, or fish on those lands, once they are "taken up." Justice Binnie noted a dearth of law as to the nature of the process to be followed by the Crown when exercising this right (the treaties themselves are silent on this point), but rejected the notion put forward by the Crown that it was entitled to "take up" lands unilaterally without consulting First Nations whose rights might be impacted. ${ }^{121}$ He stated that to accept this notion would be tantamount to promoting "a sort of 'this is surrendered land and we can do with it what we like" approach." "122 He stressed that such an approach would be the "antithesis of reconciliation and mutual respect, ${ }^{123}$ and would not accord with the honour of the Crown.

\footnotetext{
120 Mikisew, wupra note 3 at para. 11.

121 Ibid. at para. 37.

122 Jbid. at para. 49.

123 hid.
} 
The Supreme Court of Canada also rejected the Crown's assertion that any duties of consultation and accommodation with respect to the "taking up" of lands were fully discharged through the extensive consultations that took place with the Aboriginal signatories in 1899 when the treaty was negotiated. Justice Binnie held that the 1899 consultation "was not the complete discharge of the duty arising from the honour of the Crown. but a rededication of it." 124 He noted that the terms of the treaty (e.g., the Crown's treaty right to "lake up" lands from time to time) clearly contemplate a forward-looking process of treaty implementation and that it "was seen from the beginning as an ongoing relctionship that would be difficult to manage." 23 " It was held that the treaty gave rise to Mikisew procedural rights (e.g., the right to be honourably consulted) in addition to any substantive rights (e.g., the right to hunt and trap). ${ }^{126}$

Against this backdrop, the Supreme Court of Canada examined the nature and content of the duty to consult that would have been required in this particular instance. Justice Binnie noted that any consultation process, whether it is on the high or low end of the Haida spectrum (depending on the strength of the Aboriginal right asserted and the potential impact of the proposed project on that right), must be undertaken "in good faith, and with the intention of substantially addressing the conecrns of the aboriginal peoples whose lands are at issue." $127 \mathrm{He}$ defined this duly in more detail by adopting a passage of Finch J.A. (now C.J.) of the British Columbia Court of Appeal in Halfway River First Nation, ${ }^{128}$ who held that in order for the Crown to properly discharge its duty of consultation, it will always have to ensure that the interests of the Aboriginal group "are seriously considered and, wherever possible, demonstrably integrated into the proposed plan of action."'?"

The Supreme Court of Canada held that when a project contemplates any potential impact on the treaty rights of a First Nation, the Crown is not automatically obligated to consult with every First Nation that happens to be a signatory to that particular treaty. The impact on potential treaty rights is to be ascertained not on a "treaty-wide basis ... but in relation to the territories over which a First Nation traditionally hunted, fished and trapped, and continues to do so today."130

It is stated that the duty to consult will always have both "informational and response components." ${ }^{3.1}$ It is made clear in the decision that merely providing a standard package of information about a project (in the same form as that distributed to other interested stakeholders) or holding public open houses will not necessarily constitute sufficient consultation in the Aboriginal context, particularly where the applicable Aboriginal people do not participate in such open houses.

Ibid. at para. 54.

Ibid. at para. 25 [emphlasis added].

Ibid. at para. 57.

thid. at para. 61 lemphasis in orginal]. quoting De/gamumkw; stupres note 27 at para. 168 [emphasis iadded].

Halfway River Firs Nation y. British Cohumbia (Ministry of Forests), 1999 BCCA 470, 64 B.C.L.R. (3d) 206 [Halfway River First Nation].

Wikisew, stupra note 3 at para. 64 [emphasis in original], quoting ibid. at para. I60 [emphasis added]. Mikisew, ibid. at para. 48.

libid. at para. 64 . 
Justice Binnie concluded that this particular case fell at the low end of the Haida spectrum, as the potential impact on the Mikisew's treaty right to hunt and trap was relatively minor. Nevertheless, he held that the Crown still failed to discharge the requisite level of consultation. He articulated the minimum level of consultation that would have been required by the Crown in this instance as follows:

The Crown was required to provide notice to the Mikisew and to engage directly with them (and not, as seems to have been the casc here, as an aflerthought to a general public consultation with Park users). This engagement ought to have included the provision of in formation about the project alddressing what the (rown knew to be Mikisew interests and what the Crown anticipated might be the polential adverse impact on those interests. The Crown was required to solicit and to listen carefully to the Mikisew concerns. and to attempt to minimize adverse impacts on the Mikisew hunting, fishing and trapping rights. ${ }^{132}$

As further stated by Binnie J., consultation will not always lead to accommodation, and accommodation may or may not result in an agreement. In the absence of consultation, however, the Minister could not have known whether any changes were required to the road project. $^{133}$

Taken together, the decisions in Haida, Taku River, and Mikisew lay the foundation with respect to the consultation and accommodation obligations owed by the Crown to Aboriginal peoples in relation to resource development and land use activities generally.

\section{E. Key Pronouncements on Crown duties of Consultation AND ACCOMMODATION SET OUT IN HAIDA, TAKU RIVER, AND MIKISEW}

- The Crown must honourably and meaningfully consult in good faith with an Aboriginal group before authorizing or undertaking conduct that may adversely affect interests of that particular Aboriginal group.

- The obligation arises when the Crown has knowledge of the potential existence of the Aboriginal interest and is contemplating action that may adversely affect it.

- Consultation with Aboriginal groups should take place as early as possible in the project's planning stages.

- The extent of the obligation will be proportionate to: (1) the strength of the case supporting an asserted interest (if a proven right is not at issue); and (2) the seriousness of the potentially adverse effect on the applicable interest.

- Good faith consultation may reveal a duty to accommodate. The duty to accommodate involves a process of balancing interests and minimizing adverse impacts. The controlling question in all scenarios is: What is required to maintain the honour of the Crown and to effect reconciliation between the Crown and the Aboriginal interest at stake? 
- The Crown's obligation must be undertaken with the intention of "substantially addressing" "34 the Aboriginal interest at issue, and the Crown must ensure that the interest is "seriously considered and, wherever possible, demonstrably integrated into the proposed plan of action."135

- The Aboriginal group in question must also consult in good faith and must not frustrate the Crown's good faith efforts to consult.

- Neither an Aboriginal group asserting an as-yet unproven right, nor a First Nation signatory to a historical treaty claiming treaty rights, will hold a veto over the uses to which Crown land may be put.

- The obligation to consult and, where indicated, to accommodate Aboriginal interests lies with the Crown alone; there is no independent obligation on thirdparties such as project proponents. However, the Crown may delegate procedural aspects of consultation to a project proponent.

- The obligation is owed by both the provincial and the federal Crown.

- Crown obligations to consult and, where indicated, to accommodate Aboriginal interests may be satisfied through an effective administration of an applicable regulatory process. However, a determination of whether the obligations have been successfully discharged in any particular case will involve a subjective analysis, looking at the nature of the right, the nature of the infringement, and the extent of the consultation undertaken in the particular circumstances. Mere adherence to regulatory guidelines will not necessarily suffice.

- The duty will always have both informational and response components.

- When a project contemplates potential impact on historical treaty rights of a particular First Nation, the Crown is not automatically obligated to consult with each and every First Nation that happens to be a signatory to the particular treaty in question. The potential impact on treaty rights is to be ascertained "in relation to the territories over which a First Nation traditionally hunted, fished and trapped, and continues to do so today."

- First Nations that are signatories to historical treatics hold procedural treaty rights (e.g., the right to be honourably consulted), in addition to any specific substantive rights (e.g., the right to hunt and trap).

- The Crown itself has a historical treaty right (that exists in some form in all of the numbered treatics) to "take up" surrendered lands for a variety of purposes with the 
effect that certain treaty First Nations will be precluded from exercising their rights to hunt, trap, or fish on those lands. However, the exercise of this treaty right by the Crown must be honourable and must involve a process of consultation and, where indicated, accommodation of Aboriginal interests that may be adversely impacted.

\section{F. Post-haida Case Law}

There are a limited number of lower-court decisions that have applied the principles first set out by the Supreme Courn of Canada in Haida. ${ }^{137}$ Two decisions from British Columbia merit particular consideration as both provide significant guidance on the nature of the applicable Crown obligations, albeit in a context other than the approval of a natural resource development project: Musqueam Indian Band v. British Cohmbia (Minister of Sustainable Resource Management) ${ }^{138}$ and Hut-Ay-Aht First Nation v. British Columbia (Minister of Forests). ${ }^{139}$

\section{l. MUSQUEAM INDIAN BAND V. BRITSH COI.UMBIA \\ (MINISTER OF SUSTAINABLE RESOURCE MANAGEMENT)}

In Musqueam, the British Columbia Court of Appeal addressed consultation and accommodation efforts that the Province of British Columbia had undertaken before selling certain lands to the University of British Columbia on which a golf course was operated. The Musqueam Indian Band had an outstanding Aboriginal title claim to the land in question and also asserted certain Aboriginal rights that could be impacted by the proposed development. On the basis of these asserted rights and the asserted title, the Musqueam sought an interim injunction restraining the sale of the lands pending the ultimate determination of the Musqueam's Aboriginal title claim.

After the commencement of the proceedings in this instance by the Musqueam, and well after the Crown had authorized the sale of the applicable lands, the Crown initiated a consultation process with the Musqueam and attempted to accommodate the Musqueam interests that were to be adversely impacted by the sale of the lands. The Crown offered a form of economic accommodation to the Musqueam, but the two sides were unable to agree on a fair compromise.

The chambers judge dismissed the Musqueam's petition, finding that the Crown had adequately fulfilled the obligations it owed the Musqueam with respect to the sale

13. Supra nolc 1.

178 2005 BCCA 128, 37 B.C.L.R. (41h) 309 [Mfrsqueom].

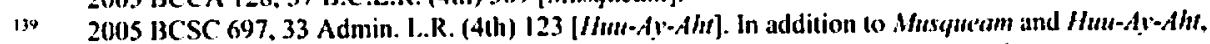
other notable decisions that have applied the principles set out in Hoida indude: Platinex, supra note

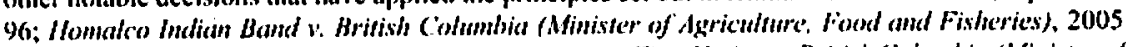

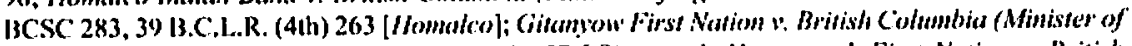
Fores/s), 2014 BCSC 1734, 38 B.C.L.R. (41h) 57 [Gitamyow]; Mnpacasath Firs Nation v. British Columbia (Minister of Forests), 2005 BCSC 1712, 5I B.C.L.R. (4th) 133 [Hupacusulh]; Betsiomiles First Natiens v. Cunada (A.G.), [2005] 4 C.N.L.R. I (Q.S.C.), rev'd [2006] Q.J. No. 3932 (C.A.)(QL); Musqueam Indian Band v. Richmond (City) 2005 BCSC 1069, 44 B.C.I.R. (4th) 326; and Paul First Nation v. Parkland (Count?), 2006 ABC A 128. 384 A.R. 366. 
transaction. The decision of the chambers judge was rendered prior to the relcase of the decisions in Haidu and Taku River. ${ }^{140}$ The Musqueam then appealed the decision to the British Columbia Court of Appeal, which heard the appeal and then reserved its decision until such time as the Supreme Court of Canada had delivered its rulings in Haida and Taku River.

The British Columbia Court of Appeal ultimately applied the principles set out in Haida and assessed the strength of the Musqueam claims in this instance and the seriousness of the potential infringements that could arise from the proposed sale transaction. Justice Southin, writing one of three judgments, noted that the Musqueam's primary concern was the diminishing land base constituting the object of its Aboriginal title claim. ${ }^{\text {IS1 }}$ The Musqueam had contended that it was unable to provide adequate housing for its members and was, through the treaty process, seeking a larger land base for this purpose, noting specifically that it was "suffering from a serious land shortage" and "facing the very real prospect of a landless treaty." 142 Justice Southin noted that the lands in question represented one of the few remaining parcels of Crown-held land in Musqueam traditional territory that could be available for the ultimate settlement of the Musqueam treaty. ${ }^{1+3}$

Taking these Musqueam concerns into account, and recognizing a relatively strong Musqueam claim to Aboriginal title over these lands, the British Columbia Court of Appeal held that the Crown had not undertaken adequate steps to consult and accommodate the applicable Musqueam interests. The Court was primarily concerned with the timing of the consultation that had taken place. Although some consultation occurred after the Crown's decision to authorize the sale, it was held that these efforts were "flawed" because they were "left until a too advanced stage in the proposed sale transaction." + t+ Given the timing of the consultation that had taken place, it was observed that the Crown was not in a position to offer any accommodation that in any way involved entitlement to the applicable land base.

In addition, given the fact that a land transfer in fee simple was contemplated in this case, the seriousness of the potential infringement was particularly high. Unlike situations involving the issuance of a project approval or associated land use permits, where the land may, in certain circumstances, remain subject to Aboriginal rights or title, the scenario in Musqueam involved a full and final disposition of a parcel of land that might otherwise become Musqueam land. If the sale was allowed to proceed as planned, Hall J.A. reasoned, the Musqueam would lose the ability to prove a claim successfully to these particular lands. ${ }^{145}$

Two aspects of the decision rendered by the Court of Appeal in Musqueam are particularly noteworthy: the remedy fashioned by the court and the commentary provided as to the substance of appropriate accommodation in these types of scenarios.

Sipra notes 1, 2.

Messuserum, supra note 138 at para. 37.

lbid, al para. 15.

lbid at paras. 37, 66.

lbid. at para. 95.

bid. at para. 94. 
First, with respect to the remedy fashioned, while Southin J.A. would have quashed the authorization of the sale transaction completely, Hall and Lowry JJ.A. ordered that the authorization merely be suspended for a period of two years in order that meaningful consultation with the Musqueam could take place. The parties were given leave to bring appropriate proceedings at the expiry of that two-year period, if necessary, to ensure that meaningful consultation be effected. ${ }^{1+6}$ It may be noted that the remedy granted in this case has had little practical effect on the University of British Columbia, which will not be able to develop the lands for a number of ycars in any event, as the lands are subject to a private lease until at least 2015 !

Second, with respect to accommodation, Hall J.A. provided some guidance on the question of appropriate, substantive accommodation. This is significant because the Supreme Court of Canada did not provide any significant commentary on this point in Haida, Taku River, or Mikisew, and becausc generally, there is a dearth of law on this point. Specifically, Hall J.A. stated:

In relatively undeveloped areas of the provinec, I stould think aceommodition might take a multiplicity of forms such as a sharing of mineral or timber resouress. One could also envisage employment agreements or land transfers and the like. This is a developing area of the law and it is too early to be at all categorical about the ambit of appropriate accommodative solutions that have to work not only for First Nations people but for all of the populace having a broad regard to the public interest. ${ }^{147}$

Justice Hall stated further that in this particular instance, there was a "fair probability that some species of economic compensation would be likely found to be appropriate for a claim involving infringement of aboriginal title relating to land of the type of this long-established public golf course located in the built up area of a large metropolis."14R

\section{HUU-AY-AIT FIRST NATION V. BRITISI COLUMBIA (MINISTER OF FORESTS)}

The second notable lower-court decision in the post-Haida jurisprudence is $H u t-A y-A h t$ First Nation v. British Columbia (Ministry of Forests). ${ }^{149}$ In $H u u-A y-A h t$, the Court was not addressing Crown consultation and accommodation efforts with respect to a particular landuse decision. Instead, the Court was addressing the specific question of whether or not the Crown's obligation to consult and accommodate was triggered in relation to the Crown's refusal to deviate from a rigid negotiating position that it was employing in discussions with

Ibid. at para. 101. See also Homalco, supra note 139, where the Court found that there was inadequate consultation in relation to an amendment to a licence held by a fish farm to permit it to raise Atlantic salmon, rather than only Chinook salmon. The Court adjourned generally the application for judicial review and directed that further consultation be undertaken, granting the parties leave to return to court for directions, and granting the llomalco leave to return to court if they felt that further consultation and accommodation were inadequals. However, the Court did not grant the full interim relicl' sought by the I Jomalco, that being the removal of all Atlantic salmon localted in the fish farm that had been moved into the lish farm pursuant to the licence amendment. Instead, the Court ordered only that no more Allantic salmon could be added to the farm until the consultation process was complete. 
the Huu-Ay-Aht as to amounts to which the latter would be entitled under a particular government program. ${ }^{1 \text { sit }}$

The main issue in Hitt-Ay-Aht was whether or not specifics of British Columbia's ongoing management of its forest revitalization plan (FRP), introduced in March 2003, offended the principles set out in Haida. It was noted that private forestry operations had been authorized and ongoing in the area in question since 1940. In regard to its applicability to Aboriginal interests, the FRP was a type of industry-wide initiative or "strategic policy approach" aimed at streamlining the consultation and accommodation of Aboriginal interests with respect to forestry in British Columbia generally. The FRP involved the setting aside of certain land tenures available for Aboriginal peoples to harvest, as well as the allocation of a lump sum amount ( $\$ 95$ million) to be available for revenue sharing with Aboriginal peoples. The land tenures set aside and the lump-sum allocation were to be used by the provincial Crown to fulfil its obligations to consult and accommodate Aboriginal interests in forestry in British Columbia until such time as the treaty process in British Columbia is complete. That is, the land tenures and lump sum were to be a one-time allocation in the pre-treaty environment in British Columbia.

The FRP contemplates the execution of Forest and Range Agreements (FRAs) with any Aboriginal group having potential rights that could be affected by forestry operations in the province. The underlying rationale of the FRP was that it provides a "fast-track" program for the accommodation of Aboriginal interests that could be adversely affected by forestry operations. Aboriginal peoples do not have the burden of proving the strength of their respective claim prior to receiving accommodation. Instcad, the Crown enters into a FRA with each applicable Aboriginal group that can meet a minimal threshold test with respect to existing rights and potential infringements. Through each FRA, which typically involves a five-year term, the Aboriginal group receives land tenures and an allocation for revenue sharing on a population-based, per capita formula. In return, the Aboriginal group acknowledges that its interests have been accommodated with respect to the economic component of administrative and operational decisions made during the term of the FRA. At the time Hutu-Ay-Aht was heard, over 100 First Nations in British Columbia had entered into FRAs with the province.

Aboriginal participation in the FRP was to be a voluntary undertaking. That is, if an Aboriginal group did not feel that a proposed FRA adequately accommodated its interests with respect to the forestry operations in question, that Aboriginal group could simply

See also Gitanyow, stipra note 139, which involved a similar challenge to the nature of Crown consultation and accommodation obligations in relation to the British Columbia FRP. In that decision, Tysen J. provided the following comment at para. 50 with respect to the rigid negoliating position being taken by the Crown:

The honour of the Crown requires it to conduct such negotiations in good faith and with a willingness to accommoxlate Aloriginal interests where necessary. The standard by which the court will assess the efforts of the Crown must, of necessity, depend on the reasonableness of the Crown's position. While the Crown may bargain hard and has no duly to reach an agreement. it must be willing to make reasenable concessions based on the strength of the Aboriginal claim and the potentially adverse effecl of the infringement in question. If the Crown does not make reasonable concessions, it is open to the court to conclude that the Crown is nol negotiating in good faith with a willingness to accommodate Aboriginal interests. 
decline the FRA. In the event that an Aboriginal group declined a FRA. the Crown would still have obligations at common law to consult and accommodate the interests of that particular group.

In this particular case, the Huu-Ay-Aht, who had a relatively small population base, had attempted to negotiate a FRA with the Crown, but ultimatcly declined based on its position that the population-based approach to compensation provided for in the FRA did not adequately accommodate specific adverse impacts of Hut- $A y-\Lambda$ ht interests, as it was not connected to the volume and value of ongoing logging on Huu-Ay-Aht traditional territory. Further, the Hutt-Ay-Aht was hesitant to enter into a FRA as it did not want to provide what it perceived to be a blanket approval in relation to certain forestry decisions on traditional Huu-Ay-Aht lands for a period of five years, particularly in light of the advanced stage of its treaty negotiations.

Prior to implementation of the FRP, the Huu-Ay-Alt had negotiated interim measures agreements (IMAs) with the Crown, which had effectively accommodated Huu-Ay-Aht interests impacted by forestry in British Columbia. Such IMAs were exceuted as part of the ongoing treaty negotiation process. The last IMA that had been executed by the Hutu- $\Lambda \mathrm{y}-\mathrm{Aht}$ and the Crown expired on 4 March 2004, approximately one year after the FRP was introduced. After the expiry of this last IMA, the Crown refused to enter into another IMA with the Huu-Ay-Aht, taking the position that the FRP mandated that parties instead enter into a FRA.

Extensive correspondence took place over several months between the Crown and the Huu-Ay-Aht in attempts to complete an agreement. However, the Crown was not prepared to negotiate any terms other than those arrived at through the standard population-based formula of the FRP. Indeed, the evidence indicated that the Crown agents who had been "negotiating" with the Huu-Ay-Aht did not hold any jurisdiction to grant accommodation beyond the scope of the FRP.

The Huu-Ay-Aht ultimately filed an application in the British Columbia Supreme Court for a declaration that, among other things, the Crown was obligated to consult in good faith with the Hutu-Ay-Aht regarding forestry permits, and for an Order directing that the Crown indeed consult in good laith with the Huu-Ay-Aht. This application was liled on 20 September 2004, approximately six months after the last IMA entered into by the Hut- $\mathrm{Ay}-$ Aht had expired. During that six month period, forestry operations continued on traditional Huu-Ay-Aht lands and various operational decisions, such as the issuance of cutting permits, were made by the Crown.

The Crown took the position in the application that it would be premature or inappropriate for the Court to interfere with an ongoing negotiation process. The Crown argued that the Haida obligation to consult and accommodate was not triggered by the Crown's general management of forestry permits and approvals, and negotiating positions taken therein, but only by specific decisions that have the potential to impact Aboriginal interests. Furthermore, the Crown argued that it had every intention of meaningfully consulting with the Huu-AyAht in the manner mandated by Haida in the event the Huu-Ay-Aht were to ultimately decide that it did not wish to enter a FRA. 
The Court did not accept the Crown's position. Looking at the fact that the Huu- $\wedge \mathrm{y}-\Lambda$ ht had never agreed to any form of accommodation (after the expiry of the most recent IMA) for the adverse impact of forestry operations on its interests, the fact that the Crown obviously had knowledge of the Huu-Ay-Aht interest in questions (as they are engaged in the formal treaty process), and the fact that forestry operations had been ongoing on the lands in question while the parties were attempting to negotiate an agreement, the Court ultimately held that, as it pertains to the ongoing forestry operations on traditional Huu-Ay-Aht territory, there had been a complete failure to consult with the Huu-Ay-Aht. ${ }^{\text {(s) }}$

The Court assessed the strength of the Huu-Ay-Aht interests and the seriousness of the potential infringement thereof and found that in this instance, the extent of consultation that would have been required was at the "higher end" of the Haida spectrum. ${ }^{152}$ This finding was based on the fact that: (1) the Huu-Ay-Aht was near the end of its treaty negotiations with the Crown; and (2) the potential infringement on Huu-Ay-Aht interest was severe in light of the considerable harvest rate contemplated on Huu-Ay-Aht traditional territory over the applicable five-year period.

The Court recognized the fact that the Huu-Ay-Aht had continually expressed its discontent with the rigid parameters of the population-based approach to accommodation offered under the FRP and noted that the Crown had never suggested any significant alternative process of consultation and accommodation. ${ }^{153}$ Indeed, the Court emphasized the fact that, as stated above, the Crown representatives negotiating with the Huu-Ay-Aht in this instance, did not have any jurisdiction to offer any accommodation to the Hut-Ay-Aht beyond the scope of the FRP mandate. Moreover, the Court alluded to the fact that the land tenures and lump-sum allocation set aside pursuant to the FRP was the entire tenure volume and provincial budget for accommodation of Aboriginal interests with respect to forestry operations in British Columbia. The ultimale implication was that an FRA was, in practical reality, the only option available to the Huu- $A y-A$ ht for the accommodation of its interests.

Against this backdrop, the Court referred to the FRP as a unilateral "imposition" and one that offended the principles set out in Haida. ${ }^{154}$

Addressing the specific arguments made by the Crown, Dillon J. stated that

Ithe question posed by the Crown is how specific the intringemem has to be beliore the duty is triggered. With respect, that is not the question. The obligation arises upon knowledge of a claim and when infringement is contemplated. It is an ongoing obligation once the knowledge component is established. II is a process. How the Crown deals with a continuing obligation is another factor. In this case, the Crown attempted to deal with the requirement to consult with a five year plan for agrecment based upon population. It was rejected by the HFN Huu-Ay-Aht First Nation]. The Crown's suggestion that a challenge should then be made on a cutblock by cutblock basis would render this process futile from the point of view of $\mathrm{HFN}$ and represents a practical take it or leave it attitude on the part |of the Crown and the absence of continuing 
consultation. When a series of operational decisions is cenainly contemplated, the duty to consult is triggered if accommodation has not been previously accepted. ${ }^{155}$

The Court thereby accepted the Huu-Ay-Aht argument that the Haida obligation is an "ongoing" obligation that may be triggered without the contemplation of one specific Crown decision, placing the emphasis instead on the knowledge and infringement components of the analysis.

Justice Dillon also commented on the substantive nature of the Crown duty to accommodate, where required, stating specifically that "[a]ccommodation begins when policy gives way to Aboriginal interests." 156

The British Columbia Supreme Court ultimately granted the declaratory relief sought by the Huu-Ay-Aht in this case. The Crown then appealed the decision but subsequently abandoned its appeal. As a result of this decision (and the fact that the Crown dropped its appeal), we anticipate changes to the FRP.

\section{Regulatory Consultation REQUiREMENTS and Provincial. Pol.jcy Developments}

In addition to any consultation obligations that may be owing by the Crown as a result of the case law addressed above, there may also be certain regulatory requirements for consultation with Aboriginal people by the Crown or by project proponents, depending on the type of project that is proposed. In addition, both Alberta and British Columbia have now issued specific provincial policy documents that purport to mandate a framework for how Crown obligations of consultation and accommodation are to be administered in each respective province. These documents are discussed below.

It should be reiterated at this point that the Crown's common law duty to consult and, where appropriate, to accommodate may be satisfied through an effective administration of applicable regulatory processes that offer sufficient opportunities for participation of Aboriginal groups. This principle was confirmed in Haida, where McLachlin C.J.C. stated:

It is open to governments to sct up regulatory schemes to address the procedural requirements appropriate to different problems at diflerent stages, thereby strengthening the reconciliation process and reducing recourse to the courts. As noted in $R$. $v$. ddems, [19\%6] 3 S.C.R. 101, at para. 54, the government "may not simply adopt an unstructured discretionary administrative regime which risks infringing aboriginal rights in a substantial number of applications in the absence of some explicit guidance". It should be observed that, since October 2002, British Columbia has had a Provincial Policy for Consultation with First Nations to direct the terms of provincial ministries' und agencies' operational guidelines. Such a policy, while falling short of a regulatory scheme. may guard against unstructured discretion and provide a guide for decision. makers. ${ }^{157}$ 
Furthermore, as noted above, it was specifically stated in Taku River that

[t] the Province was not required to develop special consultation measures to address [Tlingit] concems, outside of the process provided for by the Environmental Assessment Act, which specifically set out a scheme that required consultation with alfected Aboriginal peoples. ${ }^{158}$

In Mikisew, ${ }^{159}$ some general public notification and consultation had been undertaken in relation to an environmental assessment process under the Canadion Environmental Assessmen $A \mathrm{C}^{\text {(t)l }}$ that did not involve a review panel. The Mikisew had been informed of open-house sessions in relation to the proposed project but had decided not to participate in those sessions. As the Crown addressed the Mikisew's express concerns unilaterally and without directly engaging the Mikisew, it was eventually determined that adequate consultation had not taken place in this instance. Nevertheless, in our view Mikisew does not stand as a pronouncement that the $C E A A$ process is an insufficient mechanism for discharging the Crown's consultation obligations. A carefully designed $C E A A$ environmental assessment process may well discharge these duties. ${ }^{161}$

It should also be noted that regulatory agencies, such as the National Energy Board (NEB or the Board) and the Alberta Energy and Utilities Board (AEUB), will often act as quasijudicial decision makers and, as such, are not normally the Crown representatives that will consult directly with Aboriginal groups. Furthermore, such entities do not have fiduciary obligations to consult or accommodate Aboriginal interests when issuing project approvals. ${ }^{162}$ Rather, their mandate is generally to ensure that the applicable Crown obligations are satisfied by the appropriate Crown representatives (or project proponents) before they issue project approvals. ${ }^{163}$

Supra nole 2 at para. 40.

Sipria nole 3.

S.C. 1992 , c. $37[C E . A A]$.

We expect lurther guidance from the courts on this issue in the near luture, as Aboriginal groups seek more participation in environmental assessment processes, and in the design of mechanisms for Aboriginal involvement in various projects that are currently proposed. For cxample, the Dene Tha" First Nation is challenging the "Consultation Plan" created by various regulatory agencies in coordination with various Aboriginal groups in relation to the Mackenzie Gas Project. The Dene Tha' First Nation is arguing that it was nol adequately consulted in relation to the creation of this "Consultation Plan." The hearing of this matter took place in Vancouver on 19-23 Jume 20106; judgment was reserved. Prior to the hearing, the Crown hat applied, unsuceessfully, for an Order to have the action stayed pending the conclusion of the ongoing consultation processes in relation to the project. Sec Dene Tha First Nation v. Canada (Minister of Environment), 2006 FC 307, 21 C.IE.L.R. (3d) 27.

The NEBB raised the concem, in Quebec (A.G.) v. Canada (National Energy Board), [1994] I S.C.R. 159. that it ought not to be seen as owing fiduciary duties to Aboriginal communities in light of its status as a quasi-judicial entity. The Supreme Court of Canada accepted this argument. Contrast this decision with that in Suulcau First Nurions v. British Columbia (Oil and Gas Commission), 2004 BCSC 92.11 Admin. L.R. (4th) 210 [Sculkcan First Nations], afTd 2004 BCCA 286. [2004] 4 C.N.1.R. 340, leave to appeal to S.C.C. relused. [2004] S.C.C.A. No. 341 (QL), where the British Columbia Supreme Court determined that, throughout its decision-making process, the British Columbin Oil and Gas Commission $(O G C)$ had fieluciary and constitutional duties to engage in good faith consultations with the affected Aboriginal community. This determination was based on the OCiC"s enabling legislation, and the fact that the Court determined lhat (unlike the NEB) the OGC is not a quasi-judicial tribunal.

Sec, e.g., the memorandum released by the NEB in March 2006 entitled "Consideration of $A$ boriginal Concerns in National linergy Board Decisions," online: NEI\} < www.neb-one.gc.ca//l-eng/livelink.exe/ fetch/2000/90463/231/44/400321/A0T5X3_-_Other.pdf?nodeid 400322\&vernum=0>. 


\section{A. BRITISI COLUMBIA}

In British Columbia, many new provincially-regulated energy projects will be required to undergo an environmental assessment under the $B C E A A{ }^{164}$ This legislation, which came into force in December 2002, was an attempt by the provincial government to streamline the assessment process for major projects. Where the former environmental assessment statute in British Columbia (which was addressed in Taku River ${ }^{165}$ ) included mandatory structural requirements for consultation, the current legislation includes permissive requirements. established on a case-by-case basis. In particular, as it relates to consultation, $s .11$ of the $B C E A A$ provides that the Executive Director may determine the procedures and methods for conducting an assessment. Among other things, this discretion expressly includes the discretion to specify which Aboriginal peoples are to be consulted (by cither the project proponent or the provincial Environmental Assessment Office, or both). ${ }^{166}$

In March 2003, the Environmental Assessment office published its "Guide to the British Columbia Environmental Assessment Process." 167 The Guide is not a legal document and may be deviated from, based on specific project circumstances. The Guide states that, in accordance with legal and policy requirements, the province will consider Aboriginal interests in relation to environmental assessments to ensure that First Nations issues and concerns are identified, and the province's legal obligations toward Aboriginal people are met. The Guide encourages project proponents to contact Environmental Assessment Office staff as early as possible to determine whether there are Aboriginal people with interests that may be affected by a project, and to discuss consultation requirements. ${ }^{168}$

Certain provincially-regulated projects in British Columbia will also require various approvals from the British Columbia Oil and Gas Commission (OGC) under British Columbia legislation. ${ }^{169}$ The OGC is not a quasi-judicial entity so it does owe fiduciary duties to Aboriginal communities and applicable duties of consultation and, where indicated, accommodation. ${ }^{170}$ In respect to Aboriginal issues, the OGC has formal consultation processes in place with various Treary No. $8^{171}$ First Nations in northeast British Columbia in relation to oil and gas activities. Those processes are governed by Memoranda of

Sitpra note 110.

Sitpra note 2.

Sec also the Public Consultation Policy Reguknion, B.C. Reg. 373/2002, which sets out a duty on the Fxecutive Director to take into accouns the general policies respecting public consultation when making an order under $\mathrm{s}$. II of the BCEAA. Section 4 of this Regulation establishes a general policy for the proponent to conduct public consultation acceptable to the Execulive Director and to present the proper information regarding public consultalion underaken during the review process. Sections $4(2)$ and (3) establish a general policy that the Executive Director assess the adequacy of public consultation and to specily furher consultation activities that may be required.

Sec online: British Columbia Linvirommental Assessmemt Oflice <www.ear.gov.bc.ca/guide/2003/finalguidel-2003.pdis | the Guide|.

Sec ibid. at 9. Additionally, the Guide includes appendices that provide some general information and advice for project proponents in relation to their consultation discussions with First Natlons, and thall generally summarize the respective roles of each of the project proponents. the Linvironmental Assessment Office. and the Pirst Nations within the consultation process.

With respect to pipelines, for example, sec the "Pipeline and Facilitics Application Guide" (revised 28 May 2002), online: OGC <www.ogc.gow.bc.ca/pipelines.asp?'view-applicalionguide>.

Sec Sauhecou First Nations, supra note 162 at para. 130.

Supra note 4. 
Understanding and Agreements that have been negotiated between the province and those First Nations. ${ }^{72}$ As part of those processes, information packages are sent to First Nations regarding the proposed project and they are provided with opportunities to identify concerns they may have.

For certain provincially-regulated projects that are proposed outside of the area covered by Treaty No. 8 in British Columbia (which is the majority of the province), it is likely that Aboriginal peoples may have claims for Aboriginal title to Crown land over which the proposed project may pass. In that event, the Provincial Policy for Consultation with First Nations ${ }^{133}$ will apply to any permitting decisions related to the proposed project. While the B.C. Policy is not directly applicable to the project proponent itself, it will apply to decisions made by provincial authorities.

Generally, the B.C. Policy is to guide provincial decision makers in relation to decisions that might affect Aboriginal rights or title. The B.C. Policy does not deal with treaty rights and is not designed to address capacity building or interim measures. The method and manner of consultation is guided by the B.C. Policy, including determining the soundness of the claim for Aboriginal rights or title and assessing the possible justification for infringing those interests.

Essentially, if a decision maker concludes that a particular decision or activity requires consultation, there is then a delineated four-stage process that is to be followed: (1) initiate consultation to determine the soundness of the Aboriginal claim; (2) if sufficiently sound, determine the impact of a decision or activity on the Aboriginal interest; (3) decide whether an infringement may be justified; and (4) if an infringement is not justificd, attempt to reach a workable accommodation for the interest or to negotiate a workable resolution (failing which, the decision makers are simply to reconsider the project or to seek advice from the Ministry of the Attorney General).

It should be noted that in Haida, ${ }^{174}$ McLachlin C.J.C. made specific reference to the B.C. Policy. After indicating, as noted above, that regulatory schemes could serve as vehicles for the discharge of Crown consultation and accommodation obligations, and after cautioning against "unstructured discretionary" schemes, she then emphasized the existence of the B.C. Policy and noted that while it falls short of a "regulatory scheme," it "may guard against unstructured discretion and provide a guide for decision makers." 178

It may also be noted that in $H u m-A y-A h t$, Dillon J. addressed the question of whether the FRP was consistent with the B.C. Policy in her analysis of whether the Crown had satisfied

17. Copies of the nine applicable Mcmoranda of Understanding can he fisund online: OGC < www.oge.gov. be.ca/pubdoc.asp? view $=9>$. Seven of the nine Memoranda of Understanding agreements are currently being renegoliated.

M (October 2002), online: Government of British Columbia <www.gov.be.ca/begov/content/docs/ (a)2QS7M_0YQtuW/consultation_policy_fn.pdP [B.C. Policy].

1.4 Sipra note 1 .

'M Ihid. at para. 51. 
its obligations to consult in that case. Justice Dillon ultimately found that the FRP did not meet the requirements of the B.C. Policy. ${ }^{176}$

More recently, on 17 March 2005, a document titled "The New Relationship" was signed by each of the Province of British Columbia, the First Nations Summit, the Union of British Columbia Indian Chiefs, and the British Columbia Assembly of First Nations. ${ }^{177}$ This document mandates what is described as "a new government-to-government relationship based on respect, recognition and accommodation of aboriginal title and rights." 178 The document contemplates that the signatories are to work together to establish processes and institutions aimed at enabling "shared decision-making" regarding land-use planning. management, tenuring and resource revenue and benefit sharing, and establishing funding and distribution structures to support First Nations' capacity development and participation. One such initiative is the development of a "consultation and accommodation framework." which we understand is a priority for British Columbia and the British Columbia First Nations Leadership Council, and which is likely to supplant the B.C. Policy.

It is difficult to speculate at this point what a process of "shared decision-making" might look like and, more particularly, what it will mcan for project proponents. In the meantime, it is clear that the Province of British Columbia intends to be more proactive in its efforts to negotiate with Aboriginal groups in British Columbia with respect to land use and resource decision-making.

\section{B. AlbERTA}

The AEUB is the regulatory agency that oversees applications for any petroleum industry developments in Alberta including facilities, pipelines, or wells. ${ }^{170}$ The AEUB publishes Directive 056: Energy Development Applications and Schechles, ${ }^{\text {I80 }}$ which requires that applicants conduct a participant involvement program prior to submitting an application. This program mandates minimum consultation and notification requirements "with all potentially directly and adversely affected persons, including First Nations and Métis." are no special requirements explicitly set out in relation to Aboriginal consultation. Directive 056 does make specific reference to the Province of Alberta's formal Aboriginal consultation policy, which is addressed below ${ }^{182}$ and states that the AEUB expects project proponents to adhere to the terms of this policy document. ${ }^{|x|}$

Huth-dy-dhr, sitpra note 139 at para. 92.

This document is available online: British Columbia Ministry of Aboriginal Relations and Reconciliation <www.gov.be.ca/arr/newrelationship/down/new_relationship.pdis.

Ibid. at I.

The AEUB receives ils authority from the Alberta linergiv and Uitities Board Aci, R.S.A. 2(0). c. A-17. See online: AF.UB < www.eub.gov.ab.ea/bbs/documents/directives/directive056.pdi> [Directive 056]. Note that the new Directive 056 replaced all past versions of "Guide 56 " and look efleet on 12 September 2005.

Directive 056, ihid. al S. ALUB General Bulletin 2(10)3-22 (24 June 2003). online: AFU/B <www.cub.gov.ab.c:a/bbs/ils/gbs/pdi/gh20103-22.pdt>|Gi3 20103-22| indicates that any such rights must be "legally recognized" (sec Directive 056, ibid., s. 2.1-2.3). Sec also Tables 5.1. 5.5.6.1. 6.2. and 7.1 regarding minimum radius requirements for consultation depending on the nature of the project.

See infra note 189 and surrounding text.

Direclive 056, supra nole 180, s. 2.1. 
The general consultation section of Directive 056 addresses such matters as the nature of information that is to be disclosed, methods of addressing participant concerns and objections, and instructions with respect to properly documenting steps undertaken. ${ }^{184}$

If. after a comprehensive consultation process, there are no outstanding objections or concerns with respect to a particular project, the project applicant may file a "routine" application. If it is complete with respect to technical, safety, public consultation, and environmental requirements, then the project application may be approved without a hearing. ${ }^{189}$

If, on the other hand, there are outstanding objections or concerns by interested parties (such as Aboriginal groups), the applicant must file a "non-routine" application. Before filing such an application, applicants must attempt to resolve all outstanding concerns or objections. ${ }^{186}$ While such applications may still be granted by the AEUB (that is to say that the applicant is not required to resolve all outstanding issues), the project applicant will first have to document that it has made a "serious attempt to notify and consult all potentially affected parties and to address all of their concerns. ${ }^{" 187}$ Notwithstanding that documentation, AEUB staff may recommend appropriate dispute resolution "or further measures to ensure that concerns have been addressed properly. " Uthimately, depending on the complexity of issues in relation to the particular project, the AEUB will either reject the application (if, for example, it determines that Aboriginal concerns have not been addressed appropriately), approve the application without a hearing, or order that a full hearing take place.

It should be noted that an Aboriginal group that feels its interests have not been adequately addressed and that wishes to make submissions to the AEUB in relation to a particular project may apply to the AEUB for funding referred to as "intervener costs" in order to ensure it is able to properly voice its concerns. ${ }^{189}$

In addition to this specific regulatory procedure, Alberta's resource development and land management departments are nearing, at the time of publication of this article, the formal implementation of separate "Consultation Guidelines" documents. These documents will be the offspring of two previous publications by the Province of Alberta: The Government of Alberta's First Nations Consultation Policy on Land Management and Resource

lbid., ss. 2.2-2.3.

Ibid. Also, for one judicial summary of the AEUB's expectations in this regard, though based on an old version of Guide 56 , which did not use the "directly and adversely affected" test for detcrmining who must be consulted, see ALUB Decision 99-02: Shell Cansda L.ted. Application to Construct and Operate an Oil Sands Mine in the forf McMurray Area (12 February 1999). online: AEUB <www.eub.gov.ab.ca/BBS/decisions/energydecisions/1999/d99-02.pdf> at 13, where some examples of "unsatisfactory consultation" were said to include "failure to communicate with all alfecled parties, misleading communications, inadequale project information, or discussions carricd out in bad laith."

Directive 056, ibid., s. 2.3.3.

GB 2003-22, stuma note 181 at 1.

lbid.

See AEUB Directive 031A: Guidelines for Energy Cost Claims (June 2001), online: AEUB <www.eub.ca/docs/documents/directives/Directive031A.pdßs. 
Development (Alberta Policy), and A Framework for Consultation Guidelines (Alberta Framework). ${ }^{100}$

The Alberta Policy, published in May 2005, sets out the following guiding principles in relation to consultation and accommodation of Aboriginal interests in Alberta generally:

- Consultation must be conducted in good faith.

- Alberta is responsible for managing the consultation process.

- Consultation will occur before decisions are made, where Land Management and Resource Development may infringe First Nations Rights and Traditional Uses.

- While each has very different roles, the consultation process requires the participation of First Nations, the Project Proponent, and Alberta.

- Alberta's consultation practices will be coordinated across departments.

- Parties are expected to provide relevant information, allowing adequate time for the other parties to review it.

- The nature of the consultation will depend on such factors as the extent of potential infringement, the communities affected, and the nature of the activities involved.

- Consultation should be conducted with the objective of avoiding infringement of First Nations Rights and Traditional Uses. Where avoidance is not possible, consultation will be conducted with the goal of mitigating such infringement.

- Consultation will occur within applicable legislative and regulatory timelines. ${ }^{191}$

Specifically, the Alberta Policy contemplates a process of both "General Consultation and Relationship Building" and "Project-Specific Consultation." General Consultation and Relationship Building is to be carried out primarily by Alberta and is essentially to involve a process of capacity building within First Nation communities whereby: development information is shared with First Nations; First Nations are consulted with respect to traditional land uses and anticipated impacts of development on those traditional land uses; and First Nations are included in the implementation of the Alberfa Policy generally. ProjectSpecific Consultation, on the other hand, is to be carried out primarily by project proponents, although Alberta will always "retain responsibility to determine whether consultation has been adequate in the circumstances." 192 The Alberta Policy also contemplates Alberta's direct 
involvement in Project-Specific Consultation in certain circumstances such as when "major projects"193 are involved.

The Alberta Policy goes on to articulate the specific roles that both the Crown ${ }^{194}$ and Aboriginal peoples, ${ }^{195}$ respectively, are to play in the consultation process. These roles are generally based on the principles articulated in Haida, Taku River, and Mikisew.

Particularly noteworthy is the fact that, unlike its British Columbia counterpart, the Alberia Policy also articulates the role of the project proponent in the consultation process:

A berti expects industry to engage in consultation based on respect, open communication and co-operation. Those who propose natural resource developments are expected to consult with and consider the views of first Nations who could be affected by their developments. Industry should incorporate traditional use data when planning their operations. Alberta expects the Project Proponem to avoid or mitigate infringentent of First Nations Rights and Traditional Uses. Alberta's expectations of the Project Proponent are as follows:

1. Provide early notitication to Alberta and to First Nations before development is authorized to preceed. to ensure they are reasonably informed about the P'roject Proponen's proposed activitics. Information should include short-term and long-range plans in the area.

2. Discuss with lirst Nations when their proposed activities may inlringe First Nations Rights and Traditional Uses.

3. Record and address issues or concems identified by the First Nations and identify how infringements were avoided or mitigaled.

4. Upon request, make available to Alberta its documentation and other information related to consultation.

5. Consider the circumstances of the project and avoid inlringement of First Nations Rights and Traditional Uses. Where avoidance is not possible, the Project Proponem is expected to make reasunable efforts to miligate the inlringement.

6. Linter into dialogue with the First Nations regarding opportunities specific to an individual project toward achievement of a positive, sustainable outcome. 196

The Alberta Framework, published in May 2006, approximately one year after the Alberla Policy, purports to set out a list of principles with which the "Consultation Guidelines" documents of each applicable Alberta government department are to be consistent. Those most relevant for oil and gas development include:

I. Guidelines will need to evolve as experience in Alberta grows and as the law related to consultation evolves. As such, Guidelines should incorporate a transparent monitoring and evaluation process and adopt an incremental approach in the development of Guidelines that allows the monitoring and evaluation process to assist and guide adjusıments as necessary.

"Major projects" are delined in the Alberta frumework, sinpra note 190 at 4. as "those for which an environmental impact assessment is required and which require a multiplicity of approvals from bourds or statutory decision-makers." Alberta Policy, supra note 190 at 4, 5 .

ive Ibid. at 6,7.

ion Ibid. at 5, 6 [emphasis in original]. 
5. Guidelines for project-specific consultation related to resource development will rellect the differing needs of different industries.

6. Guidelines will attempt to identify minimum requirements for project-specific consultation. Alberta will also encourage the development of best practices.

7. Guidelines will identify and utilize opportunities for project-specific consultation within the existing regulatory processes. Where required, regulatory amendment will be ellecled to ensure meaningful consultation can proceed.

8. Guidelines will establish a mechanism for $\Lambda$ lhera to assess the need for project-specific consultation and indicate when project-specific consultation is not required.

10. Where the Guidelines require project-specific consultation, the guidelines:

a. will require the proponent to engage with affected First Nations to ensure the precise impacts and practical avoidance, mitigation, or accommodation strategies are identified.

b. will identify what information is to be provided to First Nations, when that information should be provided, that the information be as clear and practical as possible, and the time for First Nations to review and respond. First Nations will be asked to identify any polential for impact on sites or areas that are important to the exercise of First Nation Rights and Traditional Uses and make suggestions on how these might be avoided. mitigated or accommodated.

c. may provide for access to the relevant Alberna statutory decision maker for advice on the adequacy of consultations planned or undertaken and of proposed avoidance, mitigation or accommodation strategies.

d. will provide a mechanism for the relevant Alberta statutory decision maker to advise both First Nations and the proponent of their decision and the reasons for the decision.

11. For development projects which receive approval to procecd through a legislated public consultative process, such as an Fnvironmental Impact Assessmemt, the Gitidelines will set cut a distinct process to the existing processes for project-specilic First Nations consultation. ${ }^{197}$

In addition to setting out these guiding principles, the Alberta Framework also provides further comment on the respective roles in the overall consultation process of First Nations, ${ }^{19 x}$ Alberta, ${ }^{199}$ and industry. Industry's role, in relation to both general consultation and projectspecific consultation, is articulated as follows:

a. General Consultation: Industry will be expected to participate in some aspects of general consultation by, for example, providing data or information during land or resource planning processes or hy participating in the regional tables, where appropriale.

b. Project-Specific Consultation: When Alberta's assessment of a project indicales there is potential for adverse impact on First Nation Rights and Traditional Uses, the proponent may be required to engage the affected First Nations in project-specific consultation. The objective of this discussion is to provide the necessary details about the project to the First Nations so as to confirm whether there is an adverse impact and, if so, to develop praclical strategies to avoid or miligate the impact, such as changing the site of the project. If there are no adverse impacts. then no further activity is required. 
In either case, the proponent will be required to file a report with Alberta and fonward a copy to the First Nations. ${ }^{200}$

Also in May 2006, when it published its final version of the Alberta Framework, Alberta published draft versions of its "Consultation Guidelines" documents in relation to four government departments: Environment, Energy, Sustainable Resource Development, and Community Development. Each contain some specific consultation requirements in relation to regulatory processes coming under the purview of the applicable department. The "Consultation Guidelines" have been finalized and came into effect on 1 September 2006. ${ }^{201}$

As an example, the draft guidelines of Alberta Environment, which purport to outline additional steps to both the regulatory authorization process as defined within the Environmental Protection and Enhancement $\mathrm{Act}^{202}$ and the Canada Water Act, ${ }^{203}$ and the Environmental Impact Assessment process, specify that they apply to any projects requiring an Environmental Impact Assessment, large scale industrial projects (new projects and major expansions), large scale water diversion or water works projects, and projects in close proximity to reserves. Proponents of such projects are required to submit to Alberta Environment certain, specified project-specific information. On receipt of such information, Alberta Environment will conduct a project assessment to determine whether or not the project requires First Nations consultation.

For projects that are determined to require First Nations consultation, there are a number of steps the project proponent will have to take, including the development and implementation of a "First Nations Consultation Plan." The guidelines delineate mandatory requirements for such plans, including the specific First Nations that are to be consulted, delivery methods for the provision of information to those First Nations, the information to be provided, a consultation schedule, reporting requirements (to Alberta Environment), and specific plans to address and document First Nations concerns.

Finally, the "Consultation Guidelines" documents (along with the Alberta Policy and the Alberta Framework) are to be assessed as part of an Annual Quality Assurance Plan where First Nations, industry, and Alberta will all have input. The overall scheme contemplates an evolution of ideas and methods as part of an "incremental" approach.

\section{FEDERAL.}

The National Energy Board (NEB) is the regulatory agency with jurisdiction to approve federally regulated energy projects. ${ }^{214}$ In response to an increasing interest in the potential effects of NEB-regulated projects on Aboriginal and treaty rights, in March 2002 it issued

Ibid. at 5 .

The "Consultations Guidelines" devuments are available online: Alberta Aboriginal Affairs and Northern Development <www.aand.gov.ab.ca/AANDFlash/63DBC78C2ASD4ADD8A16645BF 110795!_AA45697388594666BA559E50167136E4.htm>.

R.S.A. 2000, c. E-12.

R.S.C. 1985, c. C. 11 .

The NEB receives its authority from the National Energr Board Act, R.S.C. 1985, c. N-7. 
a Memorandum of Guidance (MOG) entitled "Consultation with Aboriginal Peoples"205 setting out the NEB's intended approach to dealing with Crown consultation with respect to applications for projects that have the potential to interfere with Aboriginal or treaty rights. The MOG provided as follows:

The Board is of the view that, in accordance with this obligation, it has a responsibility to determine whether there has been adequate Ctown consultation before rendering its decision in cases where the eflect of the decision may interlere with an aboriginal or treaty right.

Therefore, in considering applications before it, the Board will require applicants to clearly identify the Aboriginal peoples that have an interest in the area of the proposed project and to provide evidence that there has been adequate Crown consultation where rights pursuant to section 35 of the Constirution Act, 1982 may be infringed if the Board approves the applied-for lacilitics.

In such cases, applicants will be expected to contact the appropriate Crown department or agency to ensure that the requisite Crown consultations are carried out and to arrange for the information pertaining to those consultations to be liled with the Board. In the absence of such evidence, an application may be considered delicient by the Board or questions may be posed to the applicant to clicit the necessary information.

Notwithstanding such Crown consultation activities, the Board will continuc to examine the eflorts made directly by applicants to contact potentially affected Aboriginal peoples to advise them of the project and to involve them in meaningful discussions regarding potential projeet impacts and appropriate mitigation as set out in the Board's Guidelines for Filing Requirements. ${ }^{206}$

However, in August 2004, in response to the decisions of the Supreme Court of Canada in Haida and Taku River, the NEB withdrew this MOG on the basis that it no longer reflected the current state of the law. ${ }^{207}$ At that time, the NEB formally stated that it would "continue to monitor legal and policy developments in respect of the duty to consult and will engage Aboriginal organizations and groups, industry representatives and government departments prior to issuing any future guidance document on this matter."208

In March 2006, a memorandum was issued by the NEB entitled "Consideration of Aboriginal Concerns in National Energy Board Decisions." ${ }^{209}$ This memorandum is based on the premise that the NEB is a quasi-judicial tribunal and that it "operates at arm's length from the federal government." 210 The memorandum states that the NEB requires project proponents to directly engage potentially affected Aboriginal communities prior to filing its application with the Board. In particular, the following information is set out as that required

(4 March 2002), online: NEB <www.neb-one.gc.ca/ll-eng/livelink.exe/fetch/2000/90463/231144/ $14284 \% /$ Memorandum_Of Guidance_(AOC8Q3).pdf?nodeid $=142856 \&$ verum $=0>$.

lbid, at 2-3.

See NEB. "Implications of Supreme Court of Canada Decisions on the National Encrgy Board's Memorandum of (iutdance on Consultation with Aburiginal People" (3 August 2005), online: NEB <wWw.ncb-onc.ge,ca/ll-eng/livelink.exe/fetch/2000/90463/231144/375594/A0R5U7__Letler.pdl"node id $=375541$ \& vernum -()$>$.

Ibid. at 1.

See online: NEB < www ncb-one.ge.ca/ll-eng/livelink.exe/fetch/2000/90463/231 144/40032 I/A0T5X3 _-Other.pdr?nodeid $=400322 \&$ vernum $=0>$.

ibid. at 1. 
to be included in any project application that involves land use that could impact Aboriginal or treaty rights:

- Identification of all the First Nations communities that may be affected by the project and how they were identified;

- When and how they were contacted and who was contacted;

- Evidence that the applicant has provided potentially affected Aboriginals with a project overview that clearly explains the nature of the project, its routing, proposed construction periods and possible environmental and socio-economic impacts, and information regarding its proposed measures to minimize such impacts;

- Documentation and summaries of any meetings with those potentially affected Aboriginal people. Details of confidential discussions need not be revealed but the evidence should include enough information to enable the NEB to understand the general issues discussed;

- Information as to the concerns raised by Aboriginal people, and whether or not those concerns are still outstanding or have been addressed by the applicant;

- An analysis of the potential impacts of the project on the exercise of traditional practices such as hunting, fishing, trapping, and gathering.

In addition to the requirements set out in this memorandum, chapter three of the NEB's Filing Manual comments on the design and implementation of public consultation programs, and includes specific advice regarding consultation with Aboriginal communities. ${ }^{21}$ It encourages project proponents to establish a "consultation protocol" in collaboration with any potentially affected Aboriginal groups in a way that takes into account the "needs and cultural elements" of those groups. ${ }^{212}$

(29 April 2004), online: NEB <www.nch-one.ge.ca/ActsRegulations/NEBAct/FilingManual/FMTOC_ e.htm>.

$\therefore \quad$ ibid. at 3.3.1. For a recent example of an NEB decision that refers to its guidance documents, sec NEB, Terusen Pipelincs (Trans. Moumsuin) Inc. TMX-Anchor Loop Project, Hearing Order OH-1-2006-Ruling No. 1 (24 August 2006) [Hearing Order Ruling No. I], being App. II to NEB. Terasen Pipelines (Trans Mountain) Inc. Section 52 Application dated 17 February 2006 for the TMX.Anchor Loop Project. Reasons for Decision (October 2006), online: NEB <http:/dsp-psd.pwgsc.gc.ca/ Collection/NE22-12006-4E.pdP. Hearing Order Ruling No. 1 is the Board's decision on the Motion filed by the Simpew First Nation and the CEAA process complaint letter regarding the TMX-Anchor Loop Project. In that case, the First Nation's motion, which included a request to extend the deadlines set out in the Hearing Order, was based primarily on arguments related to procedural faimess, rather than assertions of the Crown's failure to satisfy its consultation obligations. Nevertheless, it remains a relevant example of what the NEB may view as sufficient opportunities for potentially affected Aboriginal groups to participate in an environmental assessment process. In this casc, which proceeded by way of a Screening under the CEAA, the NFH concluded that on the evidence before it. the First Nation was provided numerous opportunities to nut only participate in the cnvironmental assessment process set out by the Project proponent, but to also raise any concerns about how the process was unfolding. and that they did not do so. For this reason and others (including a lack of evidence to support the First Nation's arguments), the motion was dismissed. 
With many federally regulated projects, a $C E A A$ assessment will be necessary. ${ }^{213}$ As such, while the existing $C E A A$ legislation does not specifically require that project proponents consult with Aboriginal people, consultation will be a practical necessity where a project could have potential effects on Aboriginal land uses, in that project proponents will have an obligation to put all relevant information before the responsible authority. Moreover, one of the factors a responsible authority is to consider in carrying out an assessment is the potential for "environmental effects," which are defined in the legislation as including the impact of the project on current uses of lands and resources for traditional purposes by Aboriginal people. 214

In addition, s. $4(1)($ b.3) of the $C E A A$ provides that one of the purposes of the legislation is "to promote communication and cooperation between responsible authorities and Aboriginal peoples with respect to environmental assessment. ${ }^{215}$ Section 16.1 of the $C E A A$ provides that "[c]ommunity knowledge and Aboriginal traditional knowledge may be considered in conducting an environmental assessment." 216

The practical effect of the $C E A A$ is to require responsible authorities to assess the potential effects of a project on the current use of lands and resources for traditional purposes by Aboriginal people. This in turn requires that the potentially affected Aboriginal people be consulted to determine their uses of lands and resources in the project area.

In addition to NEB requirements and requirements under the $C E A A$, other consultations may be necessary depending on the types of permits required from the various federal and/or provincial authorities in relation to any particular project.

\section{TRENDS AND CONCIUSIONS}

At the outset of this analysis, we stated that the law in relation to Crown duties of consultation and accommodation is particularly dynamic. We also stated that certain aspects of the duty remain unclear, including the role of the project proponent, the question of when the duty to accommodate is triggered, and the specific legal requirements with respect to accommodation that may be required in any particular instance. That said, there are some trends that may be observed from the recent cases, and some general conclusions that may be drawn.

It is clear that when the Crown is contemplating applications for proposed oil and gas or pipeline projects, it is obligated to consult meaningfully and honourably with any Aboriginal group (including Métis) that, to the knowledge of the Crown, may have interests that could be adversely affected by the proposed project. The scope and extent of the consultation that will be required in any particular instance will depend on the nature of the particular Aboriginal interest in question (e.g., Is it proven or asserted? Is it a right to Aboriginal title

Ibid., s. 2(1). Also, see amendments to the legislation which include specific relierences to First Nations issues: Bid., ss. 4(1)(b.3). 16.1.

215 Ibid., s. 4(1)(b.3).

216 Ibid., s. 16.1. Bill C-9 was given Royal Assent on 11 June 2003 and came into force on 30 Oetober 2003: see S.C. 2003 , c. 9. 
or a right to exercise a specific activity? Is it a right guaranteed by a historical or a modern treaty, and if so, what is the nature of that right?), and the seriousness of the potential infringement of that Aboriginal interest (e.g., Will the proposed project require a lease or licence, or an outright transfer of ownership in fee simple? How will the activity contemplated impact the Aboriginal interest in question? Will there be significant environmental impacts? What are the known or anticipated concerns of the Aboriginal group? Can these concerns be mitigated or the impact avoided?).

The courts in Canada have recently placed increased significance on both the timing of the commencement of the consultation process in any given instance, and the "response component" of that consultation process. With respect to timing, the Crown will be expected to consult with potentially affected Aboriginal groups as early as feasible to ensure that, among other things, the concerns of those particular groups may be "demonstrably integrated" into the ultimate design of the project. ${ }^{217}$ From a practical perspective, this requirement to contact Aboriginal groups early in the process will often fall to project proponents. With respect to the response component, the consultation process may be expected to involve the provision of opportunities for direct engagement of any potentially affected Aboriginal group in order that Aboriginal concerns may be most accurately ascertained and an informed and comprehensive response to those concerns may be formulated.

Environmental assessment and regulatory processes that provide meaningful opportunities to address the interests and concerns of Aboriginal people may satisfy the Crown's obligation to consult, and where indicated, to accommodate Aboriginal interests. When reviewing a consultation process, we expect that the courts will conduct a subjective analysis of whether the consultation undertaken has been meaningful and whether the Crown has acted honourably with respect to its identification of, and response to, Aboriginal interests and concerns. Therefore, the administration of a process in relation to Aboriginal consultation on a given project should be carefully considered early in project planning and should take into account the current state of the law. While decisions with respect to the final form of consultation process undertaken by the Crown in regard to any given project will be the responsibility of the Crown, a prudent project proponent will be involved from an early stage and provide its views to the Crown about an appropriate process, where opportunities for such involvement arise. The key is often to design a process that will satisfy the Crown's obligations while not causing undue delay to the overall regulatory and environmental assessment processes.

The consultation undertaken in any particular instance may lead to an indication that accommodation of Aboriginal interests or concerns is required. That is, the Crown's duty to accommodate may be triggered by findings in the consultation process. Although the courts in Canada have now more clearly defined the requirements for satisfaction of the Crown's duty to consult, to date they have provided much less guidance on the substantive nature of the Crown's duty to accommodatc. 
In Haida, McLachlin C.J.C. stated that the duty to accommodate, when triggered, will involve balancing and reconciling interests, and minimizing adverse impacts on Aboriginal rights. She also stated that accommodation may involve the Crown altering its plans with respect to a particular instance of land use. ${ }^{218}$ Indeed, Dillon J. of the British Columbia Supreme Court took this pronouncement to mean that "[a]ccommodation begins when policy gives way to Aboriginal interests." ${ }^{29}$ However, in Misqueam, Hall J.A., who wrote one of the three decisions concurring in the result, speculated that in some situations "a sharing of mineral or timber resources" or "employment agreements or land transfers," or direct "economic compensation" may form part of appropriate accommodation. He stated:

MeLachlin C.J.C. also elaborated in Hoikd on the accommodation that may be required if the consultation process suggests Crown policy should be anended. The core of accommodation is the balancing of interests and the reaching of a compromise until such time as claimed rights to property are finally resolved. In relatively undeveloped areas of the province, I should think accommodation might take a multiplicity of forms such as a slıaring of mineral or timber resources. One could also envisage employment agrectitents or land transfers and the like. This is a developing area of the law and it is ton early to be at all categorical about the ambit of appropriate accommodative solutions that have to work not only for First Nations people but for all of the populace having a broad regard to the public interest.

I should think there is a fait probability that some species of economic compensation would be likely found to be appropriate for a claim involving infringement of aboriginal title relating to land of the type of this long-established public golf course located in the built up area of a large metropolis. However, with that said, it is only fair that the consultation process seeking to lind proper accommodation should be open, transparent and timely. As I have said, that could not be said to have oceurred here because the consultation came too lale and was to a degree time constrained because the sale was virtually concluded belore any real consultation occurred. 220

Of course, in Musqueam, the Court was considering the sale in fee simple of some of the last remaining Crown land in the traditional territory of the Musqueam Nation, arguably a much greater potential impact than in the case of most proposed oil and gas projects. In contrast to Hall J.A.'s approach, the Supreme Court of Canada in Haida and Taku River2:1 instead appears to indicate the related notions of mitigation and avoidance of impacts on Aboriginal interests as the key elements of substantive accommodation. To date the Supreme Court of Canada has not endorsed the types of accommodation contemplated by Hall $\mathrm{J}$. $\mathrm{A}$. in Musqueam. We expect this point to remain contentious between Aboriginal groups, project proponents, and federal and provincial governments until such time as the Supreme Court has an opportunity to provide more guidance on the subject.

Another unresolved question is whether the Crown may delegate aspects of the duty to accommodate to a project proponent. The Supreme Court of Canada has clearly stated that the obligation to consult and, where indicated, to accommodate lies with the Crown alone, but that the Crown may delegate procedural aspects of the consultation process to project 
proponents. The Supreme Court has said nothing to the effect that the Crown may delegate substantive matters, such as accommodation obligations, to the project proponent. However, the practical reality is that the project proponent holds a direct interest in the Crown's successful discharge of its duty to consult and, where indicated, to accommodate Aboriginal interests in relation to the proponent's proposed project. Although the legal obligation is that of the Crown, the design of a suitable accommodation process, particularly where it involves substantial mitigation of impacts, will often require the direct and substantial involvement of the project proponent in order to design and implement successful and workable mitigation and/or avoidance strategies. Therefore, despite the recent case law clarifying that the duty to consult and, where indicated, to accommodate is that of the Crown alone, we foresee ongoing substantial involvement of project proponents in both the consultation and accommodation aspects of the obligation.

Finally, both the courts and provincial governments are beginning to articulate a heightened onus on Aboriginal groups to consult reasonably and in good faith and to identify clearly any concerns in relation to a particular project that is being contemplated. ${ }^{222}$ We expect this trend to continue. Nevertheless, the onus remains on the Crown to consult with Aboriginal groups in situations where the Crown contemplates conduct that may adversely affect Aboriginal rights. As the Crown has an obligation to always act honourably, we expect that reviewing courts will continue to most stringently scrutinize the actions of the Crown (as opposed to the actions of the Aboriginal group involved).

In our view, the key overarching trend in the recent case law is a repeated focus on respect, and reconciliation of Aboriginal interests with those of the broader society. In fact, recently the courts have taken a more practical rather than a legalistic focus, both in terms of the analysis of a given factual situation, and in terms of the remedies ordered. The judiciary appears to have taken to hear the closing comments of Lamer C.J.C, in Delgamuukw, that "we are all here to stay,"233 and have attempted to design remedies that require the Crown and Aboriginal groups to attempt to achieve a workable solution, while still taking into consideration the interests of third-parties like project proponents who, in many cases, have invested considerable time and money into the planning and development of a proposed project. As a result, the courts have recently been less likely to overturn a decision or quash a permit, and have instead oflen directed the Crown to continue to consult or to negotiate accommodation of Aboriginal interests.

By way of example, in Gitanyow, ${ }^{224}$ the Court gave the Minister a third chance to conduct the consultations properly. Further, the Court demonstrated a willingness to supervise matters to ensure progress was made. In various decisions, the courts have also been prepared to

:2: Similarly, in the regulatory context, see the NEB. Hearing Order Ruling No. 1, supra note 212 where the Board stated at 17:

The Board is of the view that parties to a regulatory proceeding, including First Nations, are under an obligation to raise issucs in a timely way in order to allow the applicant to respond. Furthermore, although the [First Nation] has a right to expect procedural faimess, so do other parties. As such, the Board has to weigh the lateness of this submission against the rights of other parties and, in particular, the right of the applicant to have its application heard in a timely manner.

3. Delgamuukw, supra note 27 at para. 186.

23) Supra note 139. 
grant "structural injunctions," where although declaratory relief may be granted on certain aspects of the case, other parts of the case seeking more permanent relief are adjourned while the parties engage in a consultation process and while the court remains seized of the matter. $^{225}$

In keeping with this focus on reconciliation and balancing of interests, the courts have recently clarified that even where "deep consultation" is required, Aboriginal groups with treaty rights or with asserted but unproven Aboriginal rights will not hold a veto over a given project.226 Even so, Aboriginal opposition to a proposed project in a regulatory or environmental assessment process and/or subsequent litigation create a risk of potentially significant delays to the project, and an escalation of costs. To minimize these risks, a prudent project proponent will attempt to engage potentially affected Aboriginal communities in a meaningful way and communicate often with regulatory bodies to inform them of the proponent's Aboriginal consultation program and activities. At a minimum, for most larger projects we would see this including:

- Providing adequate and accurate project information to any potentially affected Aboriginal group as early as possible and in sulficient form and detail that the group is able to identify its interests that may be affected, and the potential project effects on those interests;

- Asking the Aboriginal groups about their interests in the area (where appropriate or required by the regulator, this may include providing opportunities for involvement in traditional knowledge collection and/or traditional land use studies):

- Where appropriate, providing financial contributions toward expert assistance for the Aboriginal group to understand the nature of the project (while this is not a legal requirement, it may be a practical necessity);

- Offering meaningful opportunities for Aboriginal groups to identify potentially relevant concems;

- Listing these concerns and confirming with the Aboriginal group that the list is complete;

- Offering opportunities to work together with the Aboriginal group to identify mutually satisfactory strategies to mitigate or avoid impacts on Aboriginal interests;

- Offering to discuss with the Aboriginal group any available opportunities for project benefits (e.g., employment, contracting, or other short or long-term benefits); 
- Fully documenting any and all contacts with the Aboriginal group and listing outstanding Aboriginal concerns; and

- Informing the relevant government decision-maker(s) of such efforts so those efforts can be taken into account in the course of making project approval decisions.

By undertaking these steps, the project proponent will assist the Aboriginal group to better understand the proposed project, and to identify their concerns. Taking these steps will also assist the project proponent to obtain regulatory and environmental assessment approvals in a timely manner, and will lessen the risk of a legal challenge to those approvals.

Finally, a company's first contact with Aboriginal groups will often set the stage for a long-term relationship between these entities. If a company is considering a long-term business presence in the area of a proposed project, the relationship that develops between the parties during the project design and development stage could be of crucial importance to the long-term relationship and the ongoing success of the company's operations in the area. 